\title{
The Catalan margin during the Messinian Salinity Crisis: Physiography, morphology and sedimentary record
}

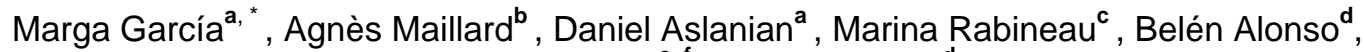 \\ Christian Gorini $^{\mathbf{e}, \mathbf{f}}$, Ferran Estrada ${ }^{\mathrm{d}}$ \\ a Département des Géosciences Marines, IFREMER, B.P. 70, 29280 Plouzané, France \\ ${ }^{\mathrm{b}}$ Université de Toulouse, UPS (SVT-OMP), LMTG, 14 Av, Edouard Belin, F-31400 Toulouse, France \\ c UMR 6538 Domaines océaniques, 1 Place Nicolas Copernic, 29280, Plouzané, France \\ d Instituto de Ciencias del Mar-CSIC, Passeig de la Barceloneta, 37-49, 08003 Barcelona, Spain \\ e UPMC Univ. Paris 06, UMR 7193, ISTEP, F-75005, Paris, France \\ ${ }^{f}$ CNRS, UMR 7193, ISTEP, F-75005, Paris, France \\ *: Corresponding author : Marga Garcia, email address : marguita.garcia@gmail.com
}

\begin{abstract}
:
The Messinian Salinity Crisis (MSC) drastically affected the physiography, morphology and sedimentation all along the Mediterranean area at the end of the Miocene. This paper presents an analysis of the effects of the MSC on the Catalan continental margin, based on a broad database of seismic reflection profiles from the oil industry and academy. We study the sedimentary processes and their controlling factors and the correlation with the nearby and well-known Gulf of Lions. Because of the complexity of the MSC, we define the Margin Erosion Surface/Top Erosion Surface (MES/TES) as the surface marking the end of the Messinian event, which allows differentiating three domains along the Catalan margin: the Creus, Girona and Barcelona domains, separated by the Palamós and Blanes canyons. The Creus domain shows an important structural control on the MES/TES physiography, while the Girona and Barcelona domains are characterized by wide and flat MSC platforms below the present-day shelf. The entire margin developed a series of complex drainage systems as the result of the Messinian sea level drop.
\end{abstract}

The location of the main valleys (Cap de Creus paleo-drainage system, Palamós and Blanes paleocanyons and the downslope-trending valleys on the Barcelona domain) was directly controlled by the structural framework. In contrast, the Barcelona paleo-drainage system and the tributaries of the Blanes and Palamós systems were excavated by direct subaerial erosion by meteoric rain in the basins limited by basement blocks, and were afterwards totally filled by the Pliocene-Quaternary sedimentation. Regarding the MSC depositional features, the major part of the eroded sediment was deposited as detrital deposits on the foot of the slope. The distribution of detrital bodies and evaporites was also structurally controlled. A Zanclean sea level rise occurring in at least two phases is confirmed by this study, in correlation with interpretations from the Gulf of Lions.

\section{Highlights}

The MES/TES surface has been studied on the Catalan margin $\rightarrow$ The major morphological features are drainage systems eroding the entire margin $>$ Messinian sea level changes and the structural framework controlled the MSC event - This study seems to confirm the Zanclean transgression occurring in two phases - The sea level rose slower during the first phase and faster during the second one.

Keywords : Valencia Basin ; Catalan Margin ; Messinian Salinity Crisis ; Sea level ; Drainage systems 


\section{Introduction}

The Messinian Salinity Crisis (MSC) has concentrated the interest of many researches since the drilling of evaporites and salt in the Mediterranean basins in the 70's (Hsü et al., 1973a,b; Ryan et al., 1973). Nevertheless, the bulk of investigations has focused on the marginal or deep evaporite basins, while only few works have dealt with the record of the MSC on the continental margins, which should be considered as key areas to link marginal to deep basins and to elaborate a global MSC scenario. In the Northwestern Mediterranean, the Gulf of Lions shelf-slope-deep basin transition has been studied thanks to a solid database (Guennoc et al., 2000; Lofi et al., 2005; Gorini et al., 2005; Bache, 2008; among others). Recent studies have also dealt with the transition from margins to deep basin on other Northwestern Mediterranean areas (Sage et al., 2005; Cornée et al., 2008; Obone Zue Obame et al., 2010) and in the Eastern Mediterranean area (Bertoni and Cartwright, 2006, 2007). More recently, a new multi-site study has allowed a synthetic approach to the study of the MSC on the Western and Eastern Mediterranean and Black Sea (Lofi et al., 2010). The Catalan continental margin is a key area for studying the correlation between the well-studied Gulf of Lions and the Valencia Basin (Fig. 1). This continental margin is particularly important because it is located at the transition of an oceanic basin margin (Gulf of Lions/Provençal Basin) and an aborted rift (Valencia Basin) represented by the NorthBalearic Fracture Zone (Maillard and Mauffret, 1999). In this complex context the local structural effects can be expected to have an important effect on the record of the Messinian events, in particular on the erosion surfaces and the resulting deposits. On the basis of these premises, this paper intends to improve the understanding of the Messinian event on the Catalan continental margin by studying the physiography and morphology of erosional and depositional features. We focus on establishing the major factors that controlled the record of the MSC event on the Catalan margin and on analyzing different interpretations for the Messinian sea level changes in the region.

\section{Geological setting}

\subsection{The Catalan Continental Margin}

The Catalan continental margin is located at the NW of the Valencia Basin in the Western Mediterranean. It is limited by the Cap de Creus to the north, by the Ebro delta to the south, and opens to the deep Provençal Basin (Fig. 1a). The Valencia Basin has developed in a complex tectonic setting. A first compressional episode occurred during the Paleogene, when the fault-related tectonic uplift on the Catalan Coastal ranges was compensated by erosion and isostatic subsidence (Gaspar-Escribano et al., 2004). At the end of the Oligocene to Early Miocene, subsequent extension, involving back-arc processes in relation to the African-European convergence started in the Gulf of Lions and propagated southwestwards to the Valencia Basin (Olivet, 1996; Jolivet et al., 2006; Bache et al., 2010). The extensional processes were not homogeneous along the basins separated by the North-Balearic Fracture Zone, as accretion occurred in the Provençal Basin while the Valencia Basin ended as an aborted rift (Maillard and Mauffret, 1999; Fig. 2). The extensional episode included a syn-rift stage (Upper Oligocene-Lower Burdigalian), responsible for the present-day half-graben structure and sediment deposition in the troughs, and a post-rift stage (Late Langhian-Present) of attenuated tectonic activity (Le Pichon et al., 1971; Bartrina et al., 1992; Roca and Guimerà, 1992; Torres et al., 1993; Roca et al., 1999b).

The pre-Cenozoic basement of the offshore Catalan continental margin shows NW-SE to NNW-SSE structures offshore the Gulf of Rosas, including the Riumors-Roses 
Basin, which forms a NW-SE-oriented trough, delimited by the Pals high and the Cap de Creus (Roca et al., 1999b). To the south, the basement presents NE-SW trending faults offshore Barcelona and Palamós, delimiting the Barcelona, Calella and SantFeliu half-grabens (Fig. 2). The basement shallows towards the proximal areas of the margin and forms two relatively flat platforms, the Malgrat high off Mataró and the Roses high seawards of the Sant Feliu half-grabens (Roca et al., 1999b; Fig. 2). Basinwards, a prominent E-W-oriented high has been identified on the basement (Maillard and Mauffret, 1999; Fig. 2). On the deep basin the presence of numerous morphological highs is the result of rifting-related volcanism (Marti et al., 1992; Maillard and Mauffret, 1993; Fig. 3). Both basement highs and volcanoes are not totally buried by the Miocene sediments but still outcrop in the Margin Erosion Surface and in the Top Erosion Surface (MES/TES) and partially in the present-day seafloor.

The pre-Messinian sedimentary record in the Catalan margin includes Lower to Upper Oligocene sediments deposited in piggyback basins during the pre-extensional episode, Lower Miocene sediments deposited in the graben troughs during the syn-rift episode and late Langhian to Messinian sequences that show a gradual transition to the post-rift stage (Roca et al., 1999b).

The Catalan continental margin has been defined as an essentially closed sedimentary system where onshore sediment sources converge to the Valencia Channel and feed the Valencia deep sea Fan (Dañobeitia et al., 1990; Amblas et al., 2006; Fig. 1). The sediment transport is controlled by submarine valleys that include two types of features, major and minor canyons. The major Palamós and Blanes canyons run from short distance (few $\mathrm{km}$ ) from the coast to the deep basin and are directly connected to minor rivers (Ter and Tordera rivers respectively, Fig. 1; Canals et al., 2004). The role of these canyons as major sediment transport pathways from the continental margin to the deep basin is enhanced during storm events and cascading processes (Palanques and Maldonado, 1985; O'Connell et al., 1985; Alonso et al., 1991, 1995; Palanques et al., 2005; Martin et al., 2006; Zúñiga et al., 2009). The minor canyons (Arenys, Besos, La Berenguera, Foix) incise the continental slope break in the southwestern part of the Catalan continental margin (Fig. 1). They are short linear downslope-trending canyons, generally without tributaries, and are apparently disconnected from fluvial sources (Canals et al., 2004). Most of these canyons connect directly to the $400 \mathrm{~km}$ long Valencia Channel (Amblas et al., 2006), which runs along the axis of the Valencia Basin, maintained by mass-transport processes and associated retrogressive slumps (Alonso et al., 1995; 2000; Fig. 1). This channel acts as the main collector of the Valencia Basin drainage network (Alonso and Maldonado, 1990; Farran and Maldonaldo, 1990; Field and Gardner, 1990; Nelson and Maldonado, 1990; Escutia and Maldonado, 1992; Palanques and Alonso, 2000). This network included the Ebro drainage system since at least the end of the Messinian event (Babault et al., 2006).

\subsection{The MSC context}

The Messinian Salinity Crisis (MSC) was an extreme event that affected the entire Mediterranean area during a relatively short period $(5.96-5.33 \mathrm{Ma})$, when the Mediterranean-Atlantic connection progressively closed, leading to the evaporative concentration of a highly saline brine (Hsü et al., 1973a,b; Krijgsman et al., 1999; Ryan, 2009; among others). The subsequent sea level fall exposed the margins to subaerial erosion while a thick evaporite sequence was deposited in the basin (Hsü et al., 1973a,b; Montadert et al., 1978; Rouchy and Caruso, 2006; Ryan, 2009). Following the new synthetic nomenclature (CIESM, 2008; Lofi et al., 2010), the evaporite sequence includes: the Lower Unit (LU), the Mobile Unit (MU), and the Upper Unit (UU). The material eroded from the margins was deposited downslope in the form of 
seaward prograding sets and/or fan-shaped deposits showing chaotic seismic facies (Clauzon, 1978; Barber, 1981; Stampfli and Höcker, 1989; Guennoc et al., 2000; Lofi et al., 2003, 2005; Maillard et al., 2006; Ottes et al., 2008; Bache et al., 2009; Ryan, 2009; Lofi et al., 2010).

The Zanclean flood sealed the end of the MSC at $5.33 \mathrm{Ma}$ (Hilgen and Langereis, 1993; Lourens et al., 2004). This event at 5.33 Ma has received several interpretations, from a catastrophic water flow lasting a few years (Blanc, 2002; García-Castellanos et al., 2009) to a progressive flooding occurring in two different phases of rising sea level (Bache, 2008; Bache et al., 2009). After the MSC, the presence of the salt induced salt tectonism, with the development of listric faults affecting the Pliocene-Quaternary deep sea sedimentation (Gaullier and Bellaiche, 1996; Dos Reis et al., 2004, 2005).

\subsection{The MSC in the Valencia Basin}

The Valencia margin is characterized by the polygenic Margin Erosion Surface (MES) related to a succession of erosional events upslope, and by the existence of detrital bodies (Fig. 3). Towards the Valencia basin, the Messinian depositional units are bracketed by a Basal Erosion Surface (BES) and a Top Erosion Surface (TES), which marks the last Messinian erosional event (Maillard et al., 2006). Numerous submarine valleys eroded the Catalan continental margin. They formed a convergent network of tributaries that flew down into the deep Valencia paleo-channel, which cut the TES in the basin (Escutia and Maldonado, 1992; Fig. 3). Only some of these MSC canyons are active today (Foix, Blanes, Palamós; Fig. 1), while many others cannot be identified in the present-day bathymetry (Figures 1 and 3; Escutia, 1992; Escutia and Maldonado, 1992; Tassone et al., 1996). Onshore, the Messinian event has also been identified, in the form of Messinian canyons along or close to the present-day Llobregat and Besos rivers (Vicente i Castell, 1986; Ventanyol et al., 2002; Parcerisa et al., 2008), and a Messinian NW-SE-oriented trough that connected to the Riumors-Roses marine basin on the Alt Emporda area (Escuer and Fleta, 1991). After the Zanclean reflooding the Valencia Basin registered an important sedimentation in the form of canyon infilling, hemipelagic deposition and prograding units (Dañobeitia et al., 1990; Escutia and Maldonado, 1992; Bartrina et al., 1992). The Pliocene sequence is represented by a terrigenous shelf and a prograding slope infilling the Messinian valleys and depressions, and was controlled by the basinward tilting of the continental shelf (Tassone et al., 1996). The Quaternary sequence presents a similar configuration, although the major glacioeustatic variations have substituted tectonics as the major controlling factor (Ercilla et al., 1994; Tassone et al., 1996) as also observed in the Gulf of Lions (Rabineau et al., 2006).

\section{Methodology and dataset}

This study is based on a seismic database that includes seismic profiles obtained during several scientific cruises and oil industry seismic profiles obtained from the SIGEOF database of the Instituto Geologico y Minero de España (IGME, www.igme.es) (Fig. 4a). This database has provided to the public a wide amount of seismic profiles in the form of TIFF files (scanned profiles) and the associated navigation files. The conversion of the TIFF files into SEGY files was performed with the Image2SEGY software (Farran, 2008; http://www.icm.csic.es). This software converts the pixels of the TIFF image into values of amplitude, and associates these values to the navigation, producing high-quality SEGY files. For this study we have used the Kingdom Suite software to construct and interpret the seismic database. 
This study of the MSC is focused on the identification of the MES/TES surface that marks the end of the Messinian event, and constitutes the base of the Pliocene. This surface corresponds to the former unique M surface defined by Ryan et al. (1973), and is defined today as the MES on the continental margins (no MSC deposits) and as the TES on the basins, on top of the basin MSC deposits. The information from several drilling sites, both from the oil industry and scientific drillings, has been used to establish the chronostratigraphy of the seismic profiles and to identify the MES/TES. Besides the predominant erosive character of the surface, marked by the truncation of the underlying reflections, other seismic criteria taken into account are (Fig. 4b): 1) variation in the frequency of seismic reflections, between the Miocene and the Pliocene megasequences; 2) changes in the tectonic imprint, generally from a more-tectonised pre-MSC unit to a less-disturbed Pliocene-Quaternary unit (Gorini et al., 2005); 3) Prograding clinoforms overlying the MES/TES; and 4) double high-amplitude reflection in the basin (Escutia and Maldonado, 1992). For the calculation of gradients on the MES/TES, a two-layer velocity model has been applied, assuming a value of $1500 \mathrm{~ms}^{-1}$ for the speed of sound in seawater and $2290 \mathrm{~ms}^{-1}$ as an average value for the Pliocene-Quaternary sediments (Maillard et al., 2006).

\section{Results}

\subsection{Physiography and morphology of the MES/TES}

The Catalan Messinian continental shelf was $3-25 \mathrm{~km}$ wide, with minimum widths toward the northern sector (off Cap de Creus and Cap de Begur) (Fig. 5), The width and depth increases towards the south, where the shelf forms two relatively flat platforms (from 0 to $0.5 \mathrm{~s}$ TWTT; inclined seaward at present day) limited by two prominent valleys that correspond to the present-day Palamós and Blanes canyons. Two small flat platforms also occur off Cap de Begur (5-15 km wide and from 0 to 0.5$0.7 \mathrm{~s}$ deep) and off Barcelona (10 km wide, from 0 to $1-1.1 \mathrm{~s}$ deep). The continental slope is $25-45 \mathrm{~km}$ wide and runs from $0.3-0.5$ to $2-2.5 \mathrm{~s}$ TWTT depth. The continental rise is $25-50 \mathrm{~km}$ wide (increasing its width towards the south) and occupies depths of 3.2-3.5 s, where it connects to the deep basin (Fig. 5).

On the continental slope, the MES/TES shows a sharp transition from a proximal rough, badland-type character with many valleys and incisions to a distal smooth surface gently dipping basinwards (Figures 5 and 10). This updip transition occurs at consistent depths on the seismic profiles throughout the entire study area, ranging between 1.4 and $1.7 \mathrm{~s}$ TWTT, except for the area around the Palamós paleo-drainage system, where it occurs at depths of up to $1.9 \mathrm{~s}$ TWTT.

In addition, the MES/TES on the Catalan margin was characterized by the presence of a variety of paleo-drainage systems. The Palamos and Blanes canyons were present in the MES/TES, as the first-order conduits of two well-developed paleo-drainage systems. Two other drainage systems have been identified in the MES/TES, but do not exist today: the Cap de Creus paleo-drainage system (Gulf of Rosas), also consisting of a relatively complex and hierarchic network of valleys, and the Barcelona paleodrainage system, consisting of a single valley. The domains and the paleo-drainage systems will be described in detail in the next sections.

On the base of the morphology of the MES/TES and its relationship with the structural features, the Catalan continental margin can be subdivided into three well-differentiated domains (Fig. 5). From north to south: the Creus domain extends between the Cap de Creus and the Palamós Canyon; the Girona domain is limited by the Palamós and the 
Blanes canyons; and the Barcelona domain extends from the Blanes canyon to the southern limit of the study area.

\subsubsection{The Creus domain}

The morphology of the MES/TES on the Creus domain is strongly affected by the basement, and globally coalesces with it (Figs. 5 and 6). The basement outcrops in the proximal coastal areas along the entire domain and forms numerous morphological highs (Fig. 6). The basement forms a NW-SE-oriented elongated outcrop off the Begur Cape, named Pals high (Fig. 2; Roca et al., 1999b). Numerous morphological scarps can be identified in the proximal areas at the borders of the basement outcrops, but also at deeper areas, where they seem to be related to NNW-SSE to NW-SE-trending faults (Roca et al., 1999b). Two major paleo-drainage systems have been identified in this domain: the Cap de Creus paleo-drainage system, which is located off the Gulf of Rosas, and the northern part of the paleo-Palamós drainage system, at the south of the domain (Figs. 5 and 6).

\subsubsection{The Girona domain}

In the Girona domain the MES/TES is affected by few isolated basement outcrops. The most important structural features are two prominent $\mathrm{W}$-E-oriented ridges located at the foot of the continental slope (Fig. 5). The southernmost ridge forms a $50 \mathrm{~km}$ long morphological high with a relief of up to $1.6 \mathrm{~ms}$ TWTT and gradients of up to $8^{\circ}$ on its southern side, where it outcrops in the present day seafloor. The northernmost ridge is about $30 \mathrm{~km}$ long and has a less pronounced relief, up to $1 \mathrm{~s}$ TWTT, with gradients of $5^{\circ}$ where it outcrops.

On the continental shelf, the MES/TES shows a relatively shallow MSC platform (Fig. 7), limited to the NE and SW by the rims of the paleo-Palamós and paleo-Blanes drainage systems respectively (Figs. 5 and 7). This platform, with a maximum width of $25 \mathrm{~km}$, is characterized by a relatively smooth surface, with rare truncated reflections. On the flanks of this platform, as well as on the deeper areas of the continental slope, the MES/TES has an irregular and more erosive character indicated by the truncation of reflections. Its outer limit to the SE coincides with the limit of the Rosas High (Fig. 2; Roca et al., 1999b).

\subsubsection{Barcelona Domain}

In the Barcelona domain, the basement half-graben morphology controlled both the MSC platform that occupies most of the continental shelf and the slope platform located off Barcelona (Figs.5 and 8). The MSC platform, $20 \mathrm{~km}$ wide and 0.4-0.6 s deep, is bounded by scarps and is oriented in a coast-parallel direction. It coincides with the Malgrat basement high (Fig. 3), which is delimited by normal SE-dipping faults (Roca et al., 1999b). The MES/TES has a smooth character on the platform, while it is irregular and clearly erosive on the rest of the domain. An ENE-WSW-oriented valley is incised at the western part of the platform (the Barcelona paleo-drainage system), while the eastern part is affected by the Blanes paleo-drainage system (Figs. 5 and 8). The major part of the continental slope at the western part of this domain presents numerous downslope-trending parallel valleys spaced 8 to $10 \mathrm{~km}$, with widths of 5-10 $\mathrm{km}$ and incision depths of 0.5-1.1 s (Fig. 5). 


\subsection{Paleo-drainage systems}

The Cap de Creus paleo-drainage system is located in the Creus domain, at about $30 \mathrm{~km}$ southwestward of the present-day Creus Canyon (Fig. 5). It consists of a major NW-SE oriented valley and its tributaries. The main valley is about $30 \mathrm{~km}$ long and its head is incised few kilometers from the present-day coastline. The valley location coincides with the Riumors-Roses Basin at the northern side of the Pals basement high (Figs. 2 and 5). The MES/TES shows that the transversal profile of the valley is asymmetrical and V-shaped, with $10-12 \mathrm{~km}$ wide and up to $0.9 \mathrm{~s}$ deep incisions at the proximal part. On the middle part, the profile is relatively symmetrical and U-shaped, and the valley size becomes smaller, about $5.5 \mathrm{~km}$ wide and up to $0.6 \mathrm{~s}$ deep. On the distal part, the transversal profile is also asymmetrical and U-shaped, and the valley increases its size to widths of up to $12 \mathrm{~km}$ and depths of up to $1 \mathrm{~s}$. Tributary valleys occur on the upper slope and connect with the main valley, mostly at its northern side, off Cap de Creus. They are 1-2 km wide and up to $0.6 \mathrm{~s}$ deep, are spaced few kilometers and design mesa-like reliefs with flat tops at depths of about $0.5 \mathrm{~s}$ (Fig. 6).

The Palamós paleo-drainage system consists of a major valley (the Palamós paleocanyon) at the same location than the present-day Palamós Canyon, and a dendritic network of tributary valleys (Figs. 5 and 9). The paleo-canyon is WNW-ESE-oriented. It is about $30 \mathrm{~km}$ long, 15-20 km wide and shows a V-shaped, asymmetrical profile with a steeper southwestern flank (Fig. 9). The main tributary is about $22 \mathrm{~km}$ long, has a NNW-SSE direction, and receives the input of some smaller-scale tributaries. It has widths of up to $5 \mathrm{~km}$ and incision depths of 0.5-0.6 s. This valley coincides with the NE part of the Begur Basin, which forms a narrow (2-5 km wide) trough limited by faults, at the SW side of the Pals high. On the western side, several smaller-scale tributaries have been identified, with a general WSW-ENE to SSW-NNE direction, lengths of 15$25 \mathrm{~km}$ and incision depths of up to $0.58 \mathrm{~ms}$. Those tributaries are limited by the scarps at the eastern side of the Girona domain platform and are incised in the Sant Feliu graben (Figs. 2 and 5).

The Blanes paleo-drainage system consists of a major valley (the Blanes paleocanyon), at the same location than the present-day Blanes Canyon, that limits the Girona from the Barcelona domains, and a convergent, dendritic network of tributary valleys (Fig. 5). The paleo-canyon is oriented NNE-SSW to N-S. Its head is located at less than $5 \mathrm{~km}$ from the present-day coastline and it can be followed for about $60 \mathrm{~km}$. The proximal part is narrow (up to $15 \mathrm{~km}$ wide) and shows symmetrical transversal profiles, with incision depths of up to $0.5 \mathrm{~s}$. The distal part the paleo-canyon widens to $30 \mathrm{~km}$, and presents an irregular transversal profile, mostly U-shaped and asymmetrical, with a steeper and narrower western flank (Fig. 5). The distal part cannot be precisely determined with the available data, but no relief can be identified at depths deeper than $3 \mathrm{~s}$. This valley receives tributary valleys from both the northern and southern sides. A major $15 \mathrm{~km}$ long tributary valley, 3-5 km wide and 0.25-0.45 s deep mouths into the upper paleo-canyon from the NE side. This valley also receives the input of some smaller-scale tributaries, and this secondary system is excavated into the Girona domain platform, coinciding with the Sant Feliu graben (Figs. 2 and 5). Several tributaries mouth into the main valley at its middle and distal course, both from the eastern and western sides. These tributaries have variable trends, lengths of up to 30 $\mathrm{km}$ and widths of up to $14 \mathrm{~km}$ and reach depths of $0.45 \mathrm{~s}$ (Figs. 2 and 5).

The Barcelona paleo-drainage system is incised into the eastern side of the Barcelona domain (Fig. 5). It consists of a unique, $30 \mathrm{~km}$ long valley oriented NE-SW, parallel to the present-day coastline. It is limited by well-marked scarps and is incised in the Barcelona half-graben (Figs 2 and 5). The transversal profile is irregular and U-shaped, and the incision depth reaches $0.65 \mathrm{~s}$. Width increases from about $8 \mathrm{~km}$ at the proximal 
areas to more than $10 \mathrm{~km}$ at the distal reaches. The valley orientation changes to a downslope direction at its distal part (Figures 5 and 8).

\subsection{MSC depositional units}

The limit of the MSC depositional units (detrital and evaporite deposits) has been defined by completing the initial work of Maillard et al. (2006) using all new available seismic information. The upslope limits of the detrital deposits, the Upper Unit (UU) and the Mobile Unit (MU) in the Catalan continental margin and basin are shown in Figure 10. The detrital deposits are identified on the seismic profiles as wedge-shaped units characterized by chaotic to transparent seismic facies (Fig. 10). They are generally located downslope at the transition between the MSC deposits domain and the MES domain. Basinwards they are bracketed by the BES and the TES, being therefore coeval to the MSC deposits. The depth of the upslope limit of the detrital deposits varies along the continental margin. In the Creus and Girona domains this limit occurs at depths around $3 \mathrm{~s}$ TWTT, and it generally shallows southwards and locally at the mouth of the valleys. Indeed, the distribution pattern of the detrital deposits shows a preferential deposition off the major paleo-drainage systems. In the Barcelona domain, the detrital deposits reach depths of $1.8 \mathrm{~s}$ TWTT and clear indentations exist in the Palamós and Blanes valleys and also between the E-W-oriented ridges at the foot of the Girona domain slope (Fig. 10). On the basin, UU and MU represent the Messinian deposition.

\subsection{Plio-Quaternary sedimentary record}

As a general trend, the thickness of Plio-Quaternary sediment increases basinwards. There are practically no deposits at the coastal areas, on MES platforms, basement highs and in the axis of the Palamós and Blanes canyons. The maximum values occur $(0.5$ to $1 \mathrm{~s}$ ) at the present-day shelf-edge (Fig. 11). Relatively thick deposits (up to 0.7 s) occur on the Creus and Barcelona paleo-drainage systems, as well as on the tributaries of the major paleo-valleys. The thickness of Plio-Quaternary deposits decreases slightly on the present-day continental slope and presents relatively constant values in the basin $(\sim 0.5 \mathrm{~s})$. Nevertheless, the Plio-Quaternary deposits distribution is irregular along the three domains identified in the Catalan continental margin. The Creus domain (Fig. 11), presents thin deposits $(<0.35 \mathrm{~s}$ thick) at the coastal areas and the Pals basement high while thickness increases abruptly in a downslope direction. The main depocenter of the entire study area (1.5 s) occurs on the present-day outer shelf off the Gulf of Rosas. Secondary depocenters occur on the shelf-edge south of the basement high. Plio-Quaternary deposits fill the NW tributary of the Palamós paleo-drainage system ( $0.7 \mathrm{~s}$ thick depocenter) and the Creus drainage system (up to $0.6 \mathrm{~s}$ ), whose relief cannot be identified in the present-day bathymetry. The infilling deposits consist of thick sediment wedges prograding in a SW to $S$ direction.

The Girona domain presents thin Plio-Quaternary deposits on the MSC platform $(<0.25$ s). The thickness increases abruptly on the present-day shelf-edge (up to $1 \mathrm{~s}$ ) (Fig. 11). The tributaries of the Palamós and Blanes paleo-drainage systems were also totally infilled during the Plio-Quaternary, contrasting with those at the SE side of the Blanes paleo-drainage system, which are identifiable on the present-day bathymetry. Two major depocenters ( $1 \mathrm{~s}$ thick) occur at both sides of the two E-W-oriented basement ridges at the foot of the slope. 
The Barcelona domain presents the minimum thickness of Plio-Quaternary deposits (less than $0.25 \mathrm{~s}$ ) on the platform, while the major depocenters locate on the presentday shelf-edge and upper slope $(0.7 \mathrm{~s})$, infilling the tributaries of the Blanes paleodrainage system (Fig. 11). The Barcelona paleo-drainage system and some of the valleys on the present-day continental slope are also completely filled by these deposits.

\section{Discussion}

\subsection{Geological significance of the MES/TES in the Catalan continental margin}

The physiography of the MES/TES shows a narrow continental shelf $(3-25 \mathrm{~km})$, especially on the Cap de Creus domain, where the paleo-shelf-edge, represented by the limit of the MSC platforms, is located more than $20 \mathrm{~km}$ landwards from its presentday position (Fig. 5). The most important morphologic features characterizing the MES/TES are the complex drainage systems that eroded the entire continental margin during the Messinian crisis. Drainage systems show consistent differences from the present-day ones in several aspects, including their location, their morphological parameters and their connection to the onshore and distal drainage system.

Regarding their location, only some of the Messinian paleo-valleys can be identified on the present-day seafloor (Figs. 1 and 5). This is the case of the major Palamós and Blanes canyons and of some minor downslope-trending valleys located at the southern part of the study area (Arenys and Besos canyons). They respectively correspond to the major and minor present-day submarine canyons of the Catalan continental margin. In contrast, the Creus and Barcelona paleo-drainage systems as well as most of the tributaries have been totally infilled by Plio-Quaternary deposits (Figs. 1 and 5).

A comparison between the morphological parameters (e.g. width, depth and transversal profile) of the paleo- and present day-valleys can be made for the Palamós Canyon (Fig. 9). The paleo-canyon was wider and shallower (up to $27 \mathrm{~km}$ wide and $1.1 \mathrm{~s}$ deep) than the present-day canyon, which is less than $18 \mathrm{~km}$ wide and $2.1 \mathrm{~s}$ deep. Both paired and impaired terraces occur on the paleo-canyon walls. They are 3-4 km wide and are identified at depths of $1 \mathrm{~s}$ TWTT. (Fig. 9b). Regarding the connection to onshore drainage areas, it is only documented for the Cap de Creus and the Blanes paleo-drainage systems. The Cap de Creus paleo-drainage system could be connected to the Messinian NW-SE-oriented valley in the Alt Emporda area (Fig. 2; Escuer and Fleta, 1991; Tassone et al., 1996). The downslope-trending valleys at the south of the Barcelona domain could have been connected to the valleys identified along the Besos and Llobregat rivers (Fig.2; Vicente i Castell, 1986; Ventanyol et al., 2002). For the rest of the continental margin, the connection to onshore drainage areas seems to be hindered by the Catalan Coastal Ranges (Fig. 2), which formed a morphological barrier that limited the connections to the Mediterranean Sea. Regarding the distal continuation of the paleo-drainage systems, most of them seem to lose their relief as they reach the lower continental slope. With the available data, the Palamós and Blanes paleo-canyons cannot be identified at depths greater than $2.5 \mathrm{~s}$ TWTT and the downslope-trending valleys of the Barcelona domain show no relief at depths greater than $2 \mathrm{~s}$ TWTT. 


\subsubsection{Subaerial origin of the paleo-drainage systems}

The morphology of the paleo-drainage systems, including the dendritic pattern of the drainage network and the rough character of the erosive surface with the presence of mesa-like relief at the inter-valley areas (Figs. 6 to 8), suggests an origin related to subaerial erosion as the result of the Messinian sea level drop (Barber et al., 1981; Lofi et al, 2005). Rapid retrogressive erosion, in which tributaries form a dendritic pattern draining the area between the major valleys, is suggested by the morphology of the paleo-drainage systems (Glock, 1931). Terraces and badlands topography have also been observed westward in the Ebro shelf and related to subaerial erosion (Stampfli and Hocker, 1989; Frey-Martinez et al., 2004, Urgeles et al., 2010).

Subaerial margin erosion has also been documented by several studies all around the Mediterranean, such as the Gulf of Lions (Clauzon, 1980, 1982; Guennoc et al., 2000; Lofi et al., 2003, 2005; Loget et al., 2006; Bache et al., 2009), Italy (Rizzini and Dondi, 1978), the Nile margin (Rizzini et al., 1978; Barber, 1981; Ottes et al., 2008) and the Ebro continental margin and Valencia Basin (Stampfli and Höcker, 1989; Escutia and Maldonado, 1992; Frey Martinez et al., 2004; Maillard et al., 2006). In particular, the badland Messinian surface identified on the Gulf of Lions, that presents the same character as the MES/TES on the Catalan continental margin, is interpreted to have developed subaerially in less than 0.3 Ma (Lofi et al., 2005) as the result of a retrogressive cutting of gullies, mass wasting and avalanches, in a climate dominated by intense, short rain storms (Chamley and Robert, 1980; Lofi et al., 2005).

5.1.2. The Messinian detrital deposits: relationship with the MES/TES and evaporite deposits

In the Catalan continental margin the most proximal Messinian deposits correspond to the detrital deposits, formed by sediment eroded from the shallow areas and transported by the paleo-drainage systems (Fig. 10). The varying depth of the detrital wedges (2-3 s TWTT) could be explained by a combination of different factors, including variations on the nature of the sediment supply, the occurrence of slope instability processes and local tectonic effects. Sediment eroded from different source areas in the Catalan continental margin, from the basement on the northern part of the margin to the Miocene-Oligocene sediment in the southern areas (Roca et al., 1999a,b), should be expected to undergo processes (i.e. erosion, transport, deposit) with a different degree of efficiency, leading to variable localizations of final sedimentary products. Slope instability processes favored by the deposition of evaporites and slope tilting (Govers et al., 2009; Ryan, 2009) may also be responsible for part of the detrital bodies, whereas the effect of tectonically-controlled mass movements should not be neglected. In any case, the post-depositional effect of differential subsidence must be taken into account as it changes the geometries after deposition.

Detritals are therefore proposed to come from fluvial drainage and/or slope instability. Basinwards, their precise relationship with the basin MSC deposits (LU, MU, UU) is generally complex and controversial (Lofi and Berné 2008; Bache et al., 2009; Lofi et al., 2010). In the Valencia Basin, it seems that most detritals are onlapped by the UU, which would confirm that most of the erosion and deposition would have occurred during an early stage of the MSC (Maillard and Mauffret, 2006; Bache, 2008; Bache et al., 2009). 


\subsubsection{Significance of the "rough-smooth boundary"}

The boundary between the rough and smooth MES/TES (Fig. 10) is considered as the equivalent to that identified by Bache et al. (2009) in the Gulf of Lions. Following their interpretation, the smooth surface would correspond to a first stage of slow sea level rise which progressively levels the Messinian subaerial erosion by wave ravinement abrasion, while the rough surface would be the result of the subaerial erosion preserved by a second stage of very rapid sea level rise at the end of the MSC. In the Catalan continental margin, this limit is identified at 1.4-1.7 s TWTT, approximately the same depth than in the Gulf of Lions (1.6 s TWTT). The high gradients of the MES and probably the lithology of the ridge would prevent the development of an abrasion surface around the eastern part of the E-W-oriented ridges at the Girona domain slope (Fig. 5), which explains the absence of the rough-smooth boundary in this area. At the area around the Palamós paleo-drainage system the rough-smooth boundary locates at a slightly deeper position (up to $1.9 \mathrm{~s}$ TWTT). Differential vertical movements after the MSC should be related to this fact, since the sea level variations should have affected the entire study area in a similar way.

The smooth surface could be alternatively interpreted as the result of erosion during periods of sea level stagnation along the general Messinian drawdown (as suggested by Bertoni and Cartwright, 2007), and the morphological arguments to differentiate between erosion during sealevel regression or transgression are not evident (Just et al., 2011). However, the subaerial erosion following a stagnation period during the regression would have further eroded the margin and transformed the smooth surface to a continuous rough surface, therefore not preserving the smooth surface. The position of the smooth surface landward (updip) of the detritals is another piece of argument. In the Catalan margin, while erosion during regression must definitely have happened, the preservation of the smooth surface suggests that a final erosion by wave abrasion occurred during the early Zanclean flood, when sea level rise was probably slower.

\subsection{Factors controlling the MSC imprint on the Catalan margin}

The MES/TES on the Catalan margin confirms the subaerial exposure of the margin due to the drastic sea level fall during the Messinian event and the development of the MES on the margin (Escutia and Maldonado, 1992; Frey-Martinez et al., 2004; Maillard et al., 2006; Urgeles et al., 2010). Therefore, the sea level fall can be considered as the major factor controlling the margin evolution during the MSC, since it was a unique event affecting the entire region. This major factor was however modulated by the structural framework, explaining the variations of the characteristics and features of the MES/TES along the margin.

\subsubsection{The Messinian sea level changes as the major regional factor}

The MSC sea level fall has been estimated to be of around $1500 \mathrm{~m}$ (Ryan and Cita, 1978; Clauzon, 1980; 1982), and 1500-2000 $\mathrm{m}$ in the Valencia Basin (Stampfli and Höcker, 1989; Maillard et al., 2006). The fact that Messinian valleys cannot be identified on the distal margin (>2000 m) agrees with these maximum estimations, however they should be corrected from post-depositional vertical movements. Figure 12 shows a schematic diagram of the sea level changes during the MSC and the resultant erosion surfaces and deposits. During the MSC drawdown, subaerial erosion on the margin and deposition of detrital wedges and/or evaporates occurred on the slope. Relatively short events of drastic sea level drop could have punctuated the general regressive tendency during the MSC, as suggested by the mesa-like relief 
delimiting the interfluves areas in the Cap de Creus domain (Fig. 6; Barber, 1981). The sea level drop must have induced the over-excavation of the paleo-drainage systems including the present-day onshore domain, as in the case of the Cap de Creus and Blanes paleo-drainage systems and the downslope-trending valleys at the south of the Barcelona domain. In addition, terraces identified on the paleo-canyons walls may indicate single or multiple sea level stagnancies that could be related to periods when the inflowing waters from the Atlantic kept the Western Mediterranean sea level constant at the depth of the Sicily Sill and the starting water spilling to the Eastern Mediterranean Basin (Just et al. 2010).

The Zanclean flooding would have occurred in at least two phases (Fig. 12), as suggested by the smooth/rough erosive surfaces (Bache, 2008; Bache et al., 2009). The first phase was characterized by a slow sea level rise responsible for the abrasion surface at depths of 1.4-1.7 s TWTT. This major erosive event could also be responsible for the erosion of the distal parts of the drainage systems, whose distal connection to the basinal drainage network cannot be identified. Alternatively, the absence of drainage features on the distal continental margin may be explained by a change on the sediment transport processes at the foot of the slope, from a channelized transport that developed complex drainage networks to a non-channelized transport that would spread the sediment charge on the basin. Assuming the 1500$2000 \mathrm{~m}$ of sea level drop (Stampfli and Höcker, 1989; Maillard et al., 2006), the channelized system would have consisted of subaerial rivers that would have deposited their sediment charge in the form of shallow-water deposits (in deeper areas). A second phase of rapid sea level rise allowed the preservation of the subaerial rough MES (Fig. 12; Bache, 2008; Bache et al., 2009).

After the end of the MSC, the rise in base level induced changes in accommodation space and sediment supply that led to the infilling of the Cap de Creus and Barcelona paleo-drainage systems. The first one was fossilized during the Plio-Quaternary by the sediment supply from the N-NE, as indicated by the thick prograding wedges that have induced a seaward progradation of the continental shelf of more than $20 \mathrm{~km}$ (Fig. 6). The sediment supply probably came directly from the Gulf of Lions through the LiguroProvencal current that follows the shelf edge to the west and southwest around Cap Creus both for Surficial and Intermediate, Levantine waters (Millot, 1987). In the case of the Barcelona system, the origin of the sediment is less clear from the seismic profiles, but the general NE-SW direction of the current along the margin (Millot, 1999) suggests a sediment supply from the NE.

\subsubsection{Structural framework as the major local factor}

The most important local factor is the structural framework, directly related to the North Balearic fracture zone, which separates the NE-SW-oriented Girona and Barcelona domains from the NW-SE-oriented Creus domain belonging to the Provençal Basin (Mauffret et al., 1995). The Rosas graben and Pals high are located between this fracture zone and the Central fracture zone off Barcelona (Fig. 2; Mauffret et al., 1995; Maillard and Mauffret, 1999). Even if they were not active during the Messinian, and despite the thickness of the Lower Miocene deposits (Roca et al., 1999b), the resulting faults could have acted as inherited steps. The structural framework controlled the erosional and depositional products of the MSC in different ways, determining: (1) the location and preservation of the paleo-drainage systems, both offshore and onshore; (2) the distribution of Messinian deposits; (3) the character of the erosional surface, specifically with regard to the location of the rough-smouth surface bondary; and (4) the rate of post-deposition subsidence.

Regarding the location of the major Messinian valleys, the major paleo-valleys show a 
close relationship with the structural features of the basement (Fig. 2). The Cap de Creus paleo-drainage system was controlled by the NNW-SSE-oriented faults that delimit the Riumors-Roses basin, at the NE side of the Pals high (Vázquez et al., 1993; Tassone et al., 1996; Roca et al., 1999b). The Palamós paleo-canyon was controlled by the structure of the Begur basin, which determines its NW-SE trend (Vázquez et al., 1993; Roca et al., 1999b) and the northern tributary of the Palamós paleo-drainage system was related to the NNE-SSW faults system at the SW side of the Pals high. The Blanes paleo-canyon was also incised on the basement depression between the Malgrat high and the Calella half-graben and could be controlled by the arcuate NNWSSE-oriented normal fault at the east side of the basement platform and ridge on the Girona domain (Maldonado et al., 1989; Maillard and Mauffret, 1999). The strong structural control may be also responsible for the maintenance of the major Palamós and Blanes canyons through all the Pliocene-Quaternary, probably in relation to the high-energy sediment transport during storms and cascading processes (Canals et al., 2006). On land, the structural control exerted by the physiography of the Catalan Coastal Ranges would also have determined the onshore extension of the paleodrainage systems, limiting the connections to the Gulf of Rosas and to narrow passages that allowed the incision of the Besos and Llobregat paleo-rivers.

The location of the tributaries of the major paleo-drainage systems, and the entire Barcelona paleo-drainage system may also be interpreted in relation to the structural half-graben framework. In the Girona and Barcelona domains, the differential erodibility between the basement platforms and the sediment infilling (consisting of alluvial and lacustrine successions, marine shelf deposits or fan deltas, Roca et al., 1999a) could have enhanced the effect of the meteoric rain in a graben-parallel direction, that is, parallel to the coastline, with the incision of the Barcelona paleo-drainage system and the tributaries of the Palamós and Blanes paleo-drainage systems.

Regarding the distribution of the Messinian deposits, the E-W-oriented basement ridges in the Girona domain slope seem to have acted as structural traps for the sediment eroded from shallower areas, preventing the evacuation of sediment to the deep basin. After the MSC, these ridges would have continued playing the same role, since they record more than $1 \mathrm{~s}$ TWTT thick Plio-Quaternary deposits in between ridges.

Slight differences in the location of the rough-smooth boundary on the Catalan margin may be related to differential vertical movements after the MSC, as the extensional NESW fracture playing during the Pliocene (Tassone et al., 1996) and the basinwards tilting of the margin (Lofi et al., 2003, Rabineau et al., 2006, Ryan, 2009). The division of the Valencia Basin by transfer fracture zones (Maillard and Mauffret, 1999) could determine local different response to these vertical tectonic movements and explain the distribution of Pliocene-Quaternary deposits (Fig. 11).

\section{Summary and conclusions}

The study of the MES/TES provides information about the significance of erosive and depositional features, and the role of the Messinian sea level changes and the structural framework as major controlling factors. The results of this study provide the following conclusions:

- Based on the morphological and structural features on the MES/TES surface, three domains have been differentiated: Creus, Girona and Barcelona domains, reflecting the different geological controlling factors. The major morphological features are extensive 
drainage systems that eroded the entire Catalan margin.

- The Messinian sea level drop produced subaerial erosion of the margin and deposition of detrital wedges on the slope and basin. The subaerial erosion excavated two types of drainage systems: (1) Structurally-controlled valleys that were connected to onshore drainage areas and have been preserved after the MSC. Only the Cap de Creus paleo-drainage system has been later infilled by the high sediment supply from the Gulf of Lions; and (2) Valleys excavated by meteoric rain into basins limited by basement blocks. They have been infilled by the Plio-Quaternary deposition.

- The distribution of the MSC detrital deposits was controlled by the structural framework, that determined both the nature of the sediment supply and the efficiency of the sediment transport, the reworking of deposits and the development of structural traps for the deposition of the eroded sediment.

- This study seems to confirm the Zanclean transgression occurring in two phases (Bache, 2008; Bache et al., 2009). During the first phase, the sea level rose relatively slowly and as a result of wave abrasion a smooth erosive surface developed on the margin. The second phase consisted on a rapid sea level rise that preserved the MSC features.

This work reveals the potential of the available industrial and scientific seismic profiles for the re-interpretation of regional or local geologic topics with the aid of modern software. Nevertheless, new high-resolution seismic data, especially on the slope area, are required in order to better define the precise timing of the MSC events. Regarding the chronology of the drainage systems within the Messinian crisis, two points need to be clarified: the volume of detrital deposits on the Valencia Basin and the volume of sediment eroded both onshore and offshore. This information will allow establishing the age of detrital products and to constrain an exact scenario for the MSC. Another question that should be clarified concerns the distal part of the drainage systems, regarding the connection of the paleo-valleys to the deep sediment transport and the processes involved in their formation.

\section{Acknowledgements}

This study is mainly funded by an Institut Carnot-Ifremer-EDROME grant (for Marga Garcia) and also supported by the GDR and Action-Marges Mediterranée Occidentale (France). It also benefited from the support by the Projects TOPO-MED (CGL200803474-E/BTE), CONTOURIBER (CTM2008-06399-C04-04/MAR) and MONTERA (CTM2009-14157-C02), of the Ministry of Education and Science (Spain). The authors would like to thank the effort of the Instituto Geológico y Minero de España (IGME) for making their broad industry seismic data available to the public, and Marcel.li Farran (ICM-CSIC) for his help in the transformation of seismic profiles into digital data. We thank Seismic Micro-Technologies for providing the KingdomSuite software used for the seismic stratigraphy analysis. We are grateful to Eduard Roca (UB), Jean-Loup Rubino (TOTAL), Jean-Pierre Suc (CNRS-Université de Lyon), François Bache (UPMC, CNRS) and Estelle Leroux (Université de Brest, Ifremer) for their help in the elaboration of this paper. We also thank the editors and reviewers (C. Bertoni and an anonymous reviewer) for their comments that greatly improved this paper. 


\section{References}

Alonso, B., Maldonado, A., 1990. Late Quaternary sedimentation patterns of the Ebro turbidite systems (Northwestern Mediterranean): two styles of deep-sea deposition. Marine Geology. 95, 353-378.

Alonso, B., Canals, M., Got, H., Maldonado, A., 1991. Seavalleys and related depositional systems in the Catalan Sea (Northwestern Mediterranean Sea). AAPG Bulletin 75, 1195-1214.

Alonso, B., Canals, M., Palanques, A., Rehault, J.-P., 1995. A deep-sea channel in the Northwestern Mediterranean Sea: morphology and seismic structure of the Valencia Channel and its surroundings. Marine Geophysical Researches 17, 469-484.

Alonso, B., Canals, M., Palanques, A., 2000. El Canal Medio-Oceánico de Valencia (Mediterráneo Noroccidental): procesos sedimentarios y evolución durante el Pliocuaternario, in: Alonso, B., Ercilla, G. (Eds.), Valles submarinos y sistemas turbidíticos modernos. CSIC, Barcelona, pp. 229-250.

Amblas, D., Canals, M., Urgeles, R., Lastras, G., Liquete, C., Hughes-Clarke, J.E., Casamor, J.L., Calafat, A.M., 2006. Morphogenetic mesoscale analysis of the northeastern Iberian margin, NW Mediterranean Basin. Marine Geology 234, 3-20.

Babault, J., Loget, N., Van Den Driessche, J., Castelltort, S., Bonnet, S., Davy, P., 2006. Did the Ebro basin connect to the Mediterranean before the Messinian salinity crisis? Geomorphology 81, 155-165.

Bache, F., 2008. Evolution Oligo Miocène des Marges du Micro Océan LiguroProvençal. PhD Thesis, Université de Bretagne Occidentale. 328 pp.

Bache, F., Olivet, J.L., Gorini, C., Rabineau, M., Baztan, J., Aslanian, D., Suc, J.-P., 2009. Messinian erosional and salinity crises: view from the Provence Basin (Gulf of Lions, Western Mediterranean). Earth and Planetary Science Letters 286, 139-157.

Bache, F., Olivet, J-L, Gorini, C., Aslanian, D., Labails, C., Rabineau, M., 2010. Evolution of rifted continental margins: the case of the Gulf of Lions (Western Mediterranean Basin). Earth and Planetary Science Letters 292, 345-356.

Barber, P.M., 1981. Messinian subaerial erosion of the proto-Nile Delta. Marine Geology 44, 253-272.

Bartrina, M.T., Cabrera, L., Jurado, M.J., Guimeri, J., Rota, E., 1992. Evolution of the central Catalan margin of the Valencia trough (western Mediterranean). Tectonophysics, 203, 219-247.

Bertoni, C., Cartwright, J.A., 2006. Controls on the basinwide architecture of late Miocene (Messinian) evaporites on the Levant margin (Eastern Mediterranean). Sedimentary Geology 188-189, 93-114.

Bertoni, C., Cartwright, J.A., 2007. Major erosion at the end of the Messinian Salinity Crisis: evidence from the Levant Basin, Eastern Mediterranean. Basin Research 19, 1-18.

Blanc, P.L., 2002. The opening of the Plio-Quaternary Gibraltar Strait: assessing the size of a cataclysm. Geodinamica Acta 15 (5-6), 303-317. doi:10.1016/S09853111(02)01095-1.

Canals, M., Casamor, J.L., Lastras, G., Monaco, A., Acosta, J., Berné, S., Loubrieu, B., Weaver, P.P.E., Grehan, A., Dennielou, B., 2004. The role of canyons in strata formation. Oceanography 17 (4), 80-91.

Canals, M., Puig, P., Durrieu de Madron, X, Heussner, S., Palanques, A., Fabres, J., 2006. Flushing submarine canyons. Nature 444, 354-357.

Chamley, H., Robert, C., 1980. La sédimentation argileuse au Tertiaire supérieur dans la domaine méditerranéen. Géologie Méditerraneenne 7, 25-34.

CIESM, 2008. The Messinian Salinity Crisis from mega-deposits to microbiology - A consensus report. (Brian F., Ed.). CIESM Workshop Monographs $\mathrm{N}^{\circ} 33$, Monaco, $168 \mathrm{pp}$.

Clauzon, G., 1978. The Messinian Var Canyon (Provence, southern France) Paleogeographic implications. Marine Geology 27, 231-246. 
Clauzon, G., 1980. Le Canyon de la Durance (Provence, France): une preuve paléogéographique du bassin profond de dessication. Palaeogeography, Palaeoclimatology, Palaeoecology 29, 15-40.

Clauzon, G., 1982. Le canyon Messinien du Rhône: une preuve décisive du 'dessicated deep-basin model' (Hsü, Cita and Ryan, 1973). Bulletin de la Societe Géologique de France 24, 231-246.

Cornée J.J., Maillard A., Conesa G., García F., Saint Martin J.P., Sage F., Münch P. 2008. Onshore to offshore reconstruction of the Messinian erosion surface in western Sardinia, Italy: MSC implications. Sedimentary Geology 210 (1-2), 48-60.

Dañobeitia, J., Alonso, B., Maldonado, A., 1990. Geological framework of the Ebro continental margin and surrounding areas. Marine Geology 95, 265-288.

Davis, W.M., 1909. The geographical cycle. Geographical Essays. Ginn and Co., Boston, 249-278.

Dos Reis, A.T., Gorini, C., Mauffret, A., Weibull, W., 2004. Salt tectonics, a controlling factor on the development of the Marseilles and Grand-Rhone sedimentary ridges, Gulf of Lions, Western Mediterranean Sea. C.R. Geoscience 336, 143-150.

Dos Reis, A.T., Gorini, C., Mauffret, A., 2005. Implications of salt sediment interactions for the architecture of the Gulf of Lions deepwater sedimentary systems - Western Mediterranean Sea. Marine and Petrouleum Geology 22, 713-746.

Ercilla, G., Farran, M., Alonso, B., Díaz, J.I., 1994. Pleistocene progradational growth pattern of the northern Catalonia continental shelf (northwestern Mediterranean). Geo-Marine Letters 14, 264-271.

Escuer, J., Fleta, J., 1991. Evolucion de los sistemas sedimentarios neogenos de la Cuenca del Alt Emporda (Gerona). I Congreso del Grupo Español del Terciario. Abstract volume, 113-116.

Escutia, C., 1992. Seismic stratigraphic and sedimentologic studies of the depositional environments, margin architecture and growth patterns in the Valencia Trough continental margins (Northwestern Mediterranean Sea), since the Messinian. Ph. D. Thesis, University of Barcelona.

Escutia, C., Maldonado, A., 1992. Palaeogeographic implications of the Messinian surface in the Valencia Trough, northwestern Mediterranean Sea. Tectonophysics, 203, pp. 263-284.

Farran, M., 2008. IMAGE2SEGY: Una aplicación informática para la conversión de imágenes de perfiles sísmicos a ficheros en formato SEG Y. Geo-Temas 10, 12151218.

Farran, M., Maldonado, A., 1990. The Ebro continental shelf: Quaternary seismic stratigraphy and growth patterns. Marine Geology 95, 280-312.

Field, M.E., Gardner, J.V., 1990. Pliocene-Pleistocene growth of the Rio Ebro margin, northeastern Spain: a prograding-slope model. Geological Society of America Bulletin 102, 721-733.

Frey Martinez, J.F., Cartwright, J.A., Burgess, P.M., Bravo, V.J., 2004. 3D seismic interpretation of the Messinian unconformity in the Valencia Basin, Spain. Geological Society of London 29, 91-100.

Gaullier, V., Bellaiche, G., 1996. Diapirisme liguro-provençal: les effets d'une topographie résiduelle sous le sel messinien. Apports de la modélisation analogique, Comptes Rendus de l'Académie des Sciences de Paris 322, 213-220.

García-Castellanos, D., Estrada, F., Jimenez-Munt, I., Gorini, C., Fernandez, M., Verges, J., De Vicente, R., 2009. Catastrophic flood of the Mediterranean after the Messinian salinity crisis. Nature 462, 778-781.

Gaspar-Escribano, J.M., García-Castellanos, D., Roca, E., Cloetingh, S., 2004. Cenozoic vertical motions of the Catalan Coastal Ranges (NE Spain): the role of tectonics, isostasy, and surface transport. Tectonics, 23, TC1004, doi:10.1029/2003TC001511.

Glock, W.S., 1931. The development of drainage systems: a synoptic view. Geographical Reviews 21, 475-482. 
Gorini, C., Lofi, J., Duvail, C., Dos Reis, A.T., Guennoc, P., Lestrat, P., Mauffret, A., 2005. The Late Messinian salinity crisis and Late Miocene tectonism: Interaction and consequences on the physiography and post-rift evolution of the Gulf of Lions Margin. Marine and Petroleum Geology 22, 695-712.

Govers, R., Meijer, P., Krijgsman, W., 2009. Regional isostatic response to Messinian Salinity Crisis events. Tectonophysics 463, 109-129.

Guennoc, P., Gorini, C., Mauffret, A., 2000. Histoire géologique du Golfe du Lion et cartographie du rift oligo-Aquitanien et de la surface Messinienne. Géologie de la France 3, 67-97.

Hilgen, F.J., Langereis, C.G., 1993. A critical re-evaluation of the Miocene-Pliocene boundary as defined in Mediterranean. Earth and Planetary Science Letters 118, 167-179.

Hsü, K.J., Ryan, W.B.F., Cita, M.B., 1973a. Late Miocene dessication of the Mediterranean. Nature 242, 240-244.

Hsü, K.J., Cita, M.B., Ryan, W.B.F., 1973b. The origin of the Mediterranean evaporites. Initial Reports of the Deep Sea Drilling Project, 13 (1-2). US Government Printing Office, Washington, DC, 1203-1231.

Jolivet, L., Augier, R., Robin, C., Suc, J.P., Rouchy, J.M., 2006. Lithosphericscale geodynamic context of the Messinian salinity crisis. Sedimentary Geology 188-189, 9-33.

Just, J., Hubscher, C., Betzler, C., Ludmann, T., Reicherter, K., 2011. Erosion of continental margins in the Western Mediterranean due to sea-level stagnancy during the Messinian Salinity Crisis. Geo-Marine Letters 31, 51-64.

Krijgsman, W., Hilgen, F.J., Raffi, I., Sierro, F.J., Wilson, D.S., 1999. Chronology, causes and progression of the Messinian salinity crisis. Nature 400, 652-655.

Le Pichon, X., Pautot, G., Auzende, J.-M., Olivet, J.-L., 1971. La Mediterranée Occidentale depuis l'Oligocene schema d'evolution. Earth and Planetary Science Letters 13, 145-152.

Lofi, J., Berné, S., 2008. Evidence for pre-Messinian submarine canyons on the Gulf of Lions slope (Western Mediterranean). Marine and Petroleum Geology 25, 804-817.

Lofi, J., Rabineau, M., Gorini, C., Berne, S., Clauzon, G., Clarens, P.D., Reis, T.D., Mountain, G.S., Ryan, W.B.F., Steckler, M.S., Fouchet, C., 2003. Plio-Quaternary prograding clinoform wedges of the western Gulf of Lion continental margin (NW Mediterranean) after the Messinian Salinity Crisis. Marine Geology 198, 289-317.

Lofi, J., Gorini, C., Berne, S., Clauzon, G., Dos Reis, A.T., Ryan, W.B.F., Steckler, M.S., 2005. Erosional processes and paleo-environmental changes in the Western Gulf of Lions (SW France) during the Messinian Salinity Crisis. Marine Geology 217, 1-30.

Lofi J., Deverchère J., Gorini C., Gaullier V., Gillet H., Guennoc P., Loncke L., Maillard A., Sage F., Thinon I., 2010. Atlas of the Messinian seismic markers in the Mediterranean and Black Seas. Accepted for Mémoires de la Société Géologique de France nouvelle série, Worl Geological Map Commission.

Loget, N., Davy, P., Van den Drissche, J., 2006. Mesoscale fluvial erosion parameters deduced from modelling the Mediterranean sea level drop during the Messinian (late Miocene). Journal of Geophysical Researches 111, F03005, doi:10.1029/2005JF000387.

Lourens, L.J., Hilgen, F.J., Laskar, J., Shackleton, N.J., Wilson, D., 2004. The Neogene Period, in: Gradstein, F.M., Ogg, J., Smith, A. (Eds.), A Geological Time Scale. Cambridge University Press, pp. 409-440.

Maillard, A., Mauffret, A., 1993. Structure et volcanisme dans la fosse de Valence (Méditerranée Nord-Occidentale). Bulletin de la Societe Géologique France 164, 365-383.

Maillard, A., Mauffret, A., 1999. Crustal structure and riftogenesis of the Valencia Trough (North-Western Mediterranean Sea). Basin Research 11, 357-379.

Maillard A., Mauffret A., 2006. Relationship between erosion surfaces and Late Miocene Salinity Crisis deposits in the Valencia Basin (Northwestern 
Mediterranean): evidence for an early sea-level fall. Terra Nova 18, 321-329.

Maillard, A., Gorini, C., Mauffret, A., Sage, F., Lofi, J., Gaullier, V., 2006. Offshore evidence of polyphase erosion in the Valencia Basin (Northwestern Mediterranean): scenario for the Messinian Salinity Crisis. Sedimentary Geology 188-189, 69-91.

Maldonado, A., Díaz, J.I., Escutia, C., Farrán, M., Giró, S., Serra, M., 1989. Mapa Geológico de la Plataforma Continental Española y Zonas Adjacentes. E. 1:200.000. Memoria y Hoja n 35-42E. Barcelona Instituto Geológico y Minero de España. Madrid, $117 \mathrm{pp}$.

Marti, J., Mitjavila, J., Roca, E., Aparicio, A., 1992. Cenozoic magmatism of the Valencia Trough (Western Mediterranean): relation between structural evolution and petrogenesis. Tectonophysics 203, 145-166.

Martin, J., Palanques, A., Puig, P., 2006. Composition and variability of downward particulate matter fluxes in the Palamós submarine canyon (NW Mediterranean). Journal of Marine Systems 60, 75-97.

Mauffret, A., Pascal G., Maillard, A., Gorini C., 1995. Tectonics and deep structure of the north-western Mediterranean Basin. Marine and Petroleum Geology 12 (6), 645666.

Millot, C., 1987. Circulation in the Western Mediterranean Sea, Oceanologica Acta 10 (2), 143-149.

Millot, C., 1999. Circulation in the Western Mediterranean Sea. Journal of Marine Systems 20, 423- 442.

Montadert, L., Letouzey, J., Mauffret, A., 1978. Messinian event: seismic evidence, in: Initial Reports of the Deep Sea Drilling Project, vol. 42 (1). US Government Printing Office, Washington, DC, pp. 1037-1050.

Nelson, C.H., Maldonado, A., 1990. Factors controlling late Cenozoic continental margin growth from the Ebro Delta to the western Mediterranean deep sea. Marine Geology 95, 419-440.

Obone Zue Obame, E.M., Gaullier, V., Sage, F., Maillard, A., , Lofi, J., MAURESC team. Les marqueurs sédimentaires de la Crise de Salinité Messinienne et leur relation avec la tectonique salifère: résultats de la campagne MAURESC. Bulletin de la SGF, Numéro spécial «Géodynamique et paléogéographie de l'aire méditerranéenne au Mio-Pliocène: l'interférence eustatisme- tectonique». Bulletin de la Societe Geologique France, submitted.

O'Connell, S., Alonso, B., Kastens, K.A., Maldonado, A., Malinverno, A., Nelson, C.H., Palanques, A., Ryan, W.B.F., 1985. Morphology and downslope sediment displacement in a deep-sea valley, the Valencia Valley (Northwestern Mediterranean). Geo-Marine Letters 5, 149-156.

Olivet, J.L., 1996. La cinématique de la Plaque Ibérique. Bulletin de Centres Recherche, Exploration et Production Elf Aquitaine 20, 131-195.

Ottes, W., Lambregts, P., El Barkooky, A., 2008. The Messinian Salinity Crisis in the Nile Delta: chasing shallow marine reservoirs in a deep-water basin. In: Briand, F., et al. (eds), CIESM, 2008. The Messinian Salinity Crisis from mega-deposits to microbiology - A consensus report. $\mathrm{N}^{\circ} 33$ in CIESM Workshop Monographs, Monaco. 107-109.

Palanques, A., Maldonado, A., 1985. Sedimentology and evolution of the Valencia Valley and Fan (Northwestern Mediterranean). Acta Geologica Hispanica 20, 1-19.

Palanques, A., Alonso, B., 2000. El sistema turbidítico de Valencia: características morfo-sedimentarias durante el Plio-Cuaternario, in: Alonso, B., Ercilla, G. (Eds.), Valles Submarinos y Sistemas Turbiditicos Modernos. CSIC, Barcelona, pp. 69-90.

Palanques, A., García-Ladona, E., Gomis, D., Martin, J., Marcos, M., Pascual, A., Puig, P., Gili, J.-M., Emelianov, M., Montserrat, S., Guillen, J., Tintore, J., Segura, M., Jordi, A., Ruiz, S., Basterretxea, G., Font, J., Blasco, D., Pages, F., 2005. General patterns of circulation, sediment fluxes and ecology of the Palamós (La Fonera) submarine canyon, Northwestern Mediterranean. Progress in Oceanography 66, 89119. 
Parcerisa, D., Gámez, D., Gómez-Gras, D., Usera, J., Simó, J.A., Carrera, J., 2008. Estratigrafía y petrología del subsuelo precuaternario del sector SW de la depresión de Barcelona (Cadenas costeras catalanas, NE de Iberia). Revista de la Sociedad Geologica de España 21 (3-4), 93-109.

Rabineau, M., Berné, S., Olivet, J.-L., Aslanian, D., Guillocheau, F., Joseph, P., 2006. Paleo sea levels reconsidered from direct observation of paleoshoreline position during Glacial Maxima (for the last 500,000 yr). Earth and Planetary Science Letters 252, 119-137.

Rizzini, A., Dondi, L., 1978. Erosional surface of Messinian age in the subsurface of the Lombardian Plain (Italy). Marine Geology 27, 303-325.

Rizzini, A., Vezzani, F., Cococcetta, V., Milad, G., 1978. Stratigraphy and sedimentation of a Neogene-Quaternary section in the Nile Delta area. Marine Geology 27, 327348.

Roca, E., Guimerà, J., 1992. The Neogene structure of the eastern Iberian margin: structural contraints on the crustal evolution of the Valencia trough (Western Mediterranean). Tectonophysics, 203, pp. 203-218.

Roca, E., Sans, M., Cabrera, L., 1999a. Modelo tectosedimentario del sector central y septentrional del Margen Catalán sumergido (cubetas de Barcelona, Sant Feliu, Begur y Riumors-Roses). Libro Homenaje a José Ramirez del Pozo.

Roca, E., Sans, M., Cabrera, L., Marzo, M., 1999b. Oligocene to Middle Miocene evolution of the central Catalan margin (northwestern Mediterranean). Tectonophysics 315, 209-233.

Rouchy, J.M., Caruso, A., 2006. The Messinian Salinity Crisis in the Mediterranean basin: a reassessment of the data and an integrated scenario. Sedimentary Geology 188-189, 35-67.

Ryan, W.B.F., 2009. Decoding the Mediterranean Salinity Crisis. Sedimentology 56, 95136.

Ryan, W.B.F., Hsü, K.J., et al., 1973. Initial Reports of the Deep Sea Drilling Project, 13 (1-2). U.S. Govt. Printing Office, Washington, D.C., 1447 pp.

Ryan, W.B.F., Cita, M.B., 1978. The nature and distribution of Messinian erosional surfaces - Indicators of a several-kilometer-deep Mediterranean in the Miocene. Marine Geology 27, 193-230.

Sage, F., Von Gronefeld G., Déverchère J., Gaullier V., Maillard A. and Gorini C. 2005. Seismic evidence for Messinian detrital deposits at the western Sardinia margin, northwestern Mediterranean. Marine and Petroleum Geology 22, 757-773.

Stampfli, G.M., Höcker, C.F.W., 1989. Messinian palaeorelief from 3-D seismic survey in the Tarraco concession area (Spanish Mediterranean Sea). Geology Mijnbouw 68 (2), 201-210.

Tassone, A., Roca, E., Muñoz, J.A., Cabrera, L., Canals, M., 1996. Evolución del sector septentrional del margen continental catalán durante el Cenozoico. Acta Geologica Hispanica. 29, 3-37.

Torres, J., Bois, C., Burrus, J., 1993. Initiation and evolution of the Valencia trough (Western Mediterranean): constraints from deep seismic profiling and subsidence analysis. Tectonophysics 228, 57-80.

Urgeles, R., Angelo Camerlenghi, A., Garcia-Castellanos, D., De Mol, B., Garcés, M., Vergés, J., Haslam, I., Hardman M,. 2010. New constraints on the Messinian sealevel drawdown from 3D seismic data of the Ebro Margin, western Mediterranean. Basin Research, doi:10.1111/j.1365-2117.2010.00477.x

Vazquez, J.T., Medialdea, T., Vegas, R., 1993. The NW-SE system of basins of Rosas and Bagur (northeastern continental margin of Spain). Geogaceta 14, 21-23.

Ventanyol, A., Palau, J., Roca, A., 2002. El contexto geotécnico de la Ciudad de Barcelona. Ingenieria del Terreno. IngeoTer 1. U.D. Proyectos. E.T.S.I. Minas. U.P.M. Madrid. 
Vicente i Castells, J., 1986. El plioce marí del Pla de Barcelona i del delta del Besos. Bulletin. del Centre d'Estudis de la Natura del Barcelonés Nord, Santa Coloma de Gramenet (2), pp. 52-60.

Zúñiga, D., Flexas M.M., Sanchez-Vidal, A., Coenjaerts, J., Calafat, A., Jordà, G., García-Orellana, J., Puigdefàbregas, J., Canals, M., Espino, M., Sarda, F., Company, J.B., 2009. Particle fluxes dynamics in Blanes submarine canyon (Northwestern Mediterranean). Progress in Oceanography 82(4), 239-251, doi:10.1016/j.pocean.2009.07.002.

\section{Figures}

Figure 1. Study area. a) Location and bathymetry of the Catalan margin, NW Mediterranean. b) Bathymetric chart of the study area, limited to the north by the Cap de Creus, by the Foix Canyon to the south, and opened to the deep Provençal Basin. The major submarine canyons are represented, from North to south: AC: Aude Canyon; CC: Creus Canyon; PC: Palamós Canyon; BC: Blanes Canyon; ArC: Arenys Canyon; BeC: Besos Canyon; LBC: La Berenguera Canyon; FC: Foix Canyon.

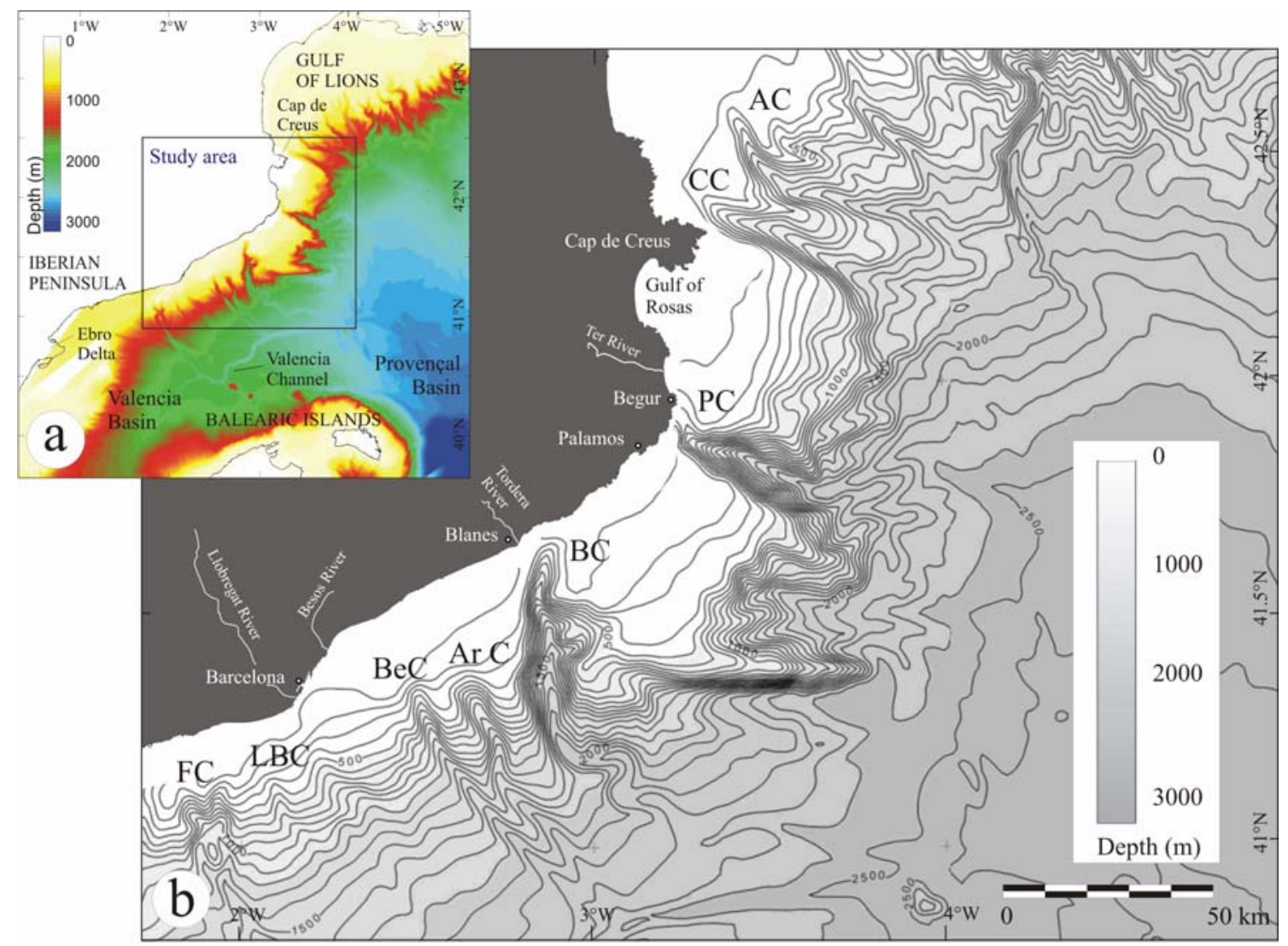


Figure 2. Structural framework of the Catalan margin. The major structural onshore and offshore features, as well as the basement isochrones, are represented. All the features represented in the map have been obtained from a bibliographic review. Legend: HG: Half-Graben; H: High.

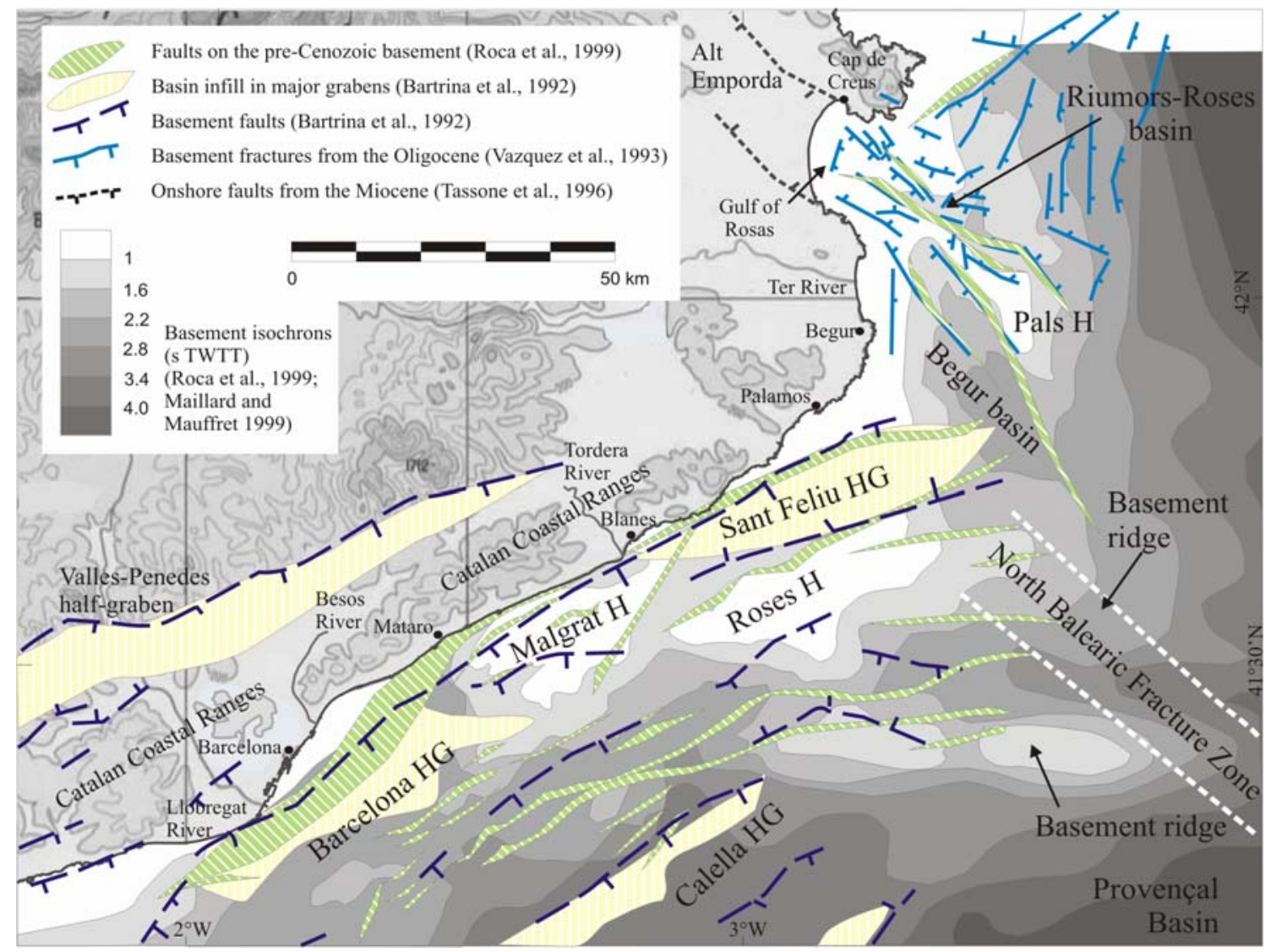


Figure 3. Synthesis of the MSC record in the Valencia Basin. MES/TES isobaths are in metres. The Messinian event is recorded in the form of erosive (Messinian valleys and erosional surfaces, MES and BES) and depositional (detrital bodies and evaporites) features. Volcanism and salt diapirs are common features in the area. Modified from Maillard et al. (2006) and Bache et al. (2009) for the Gulf of Lions

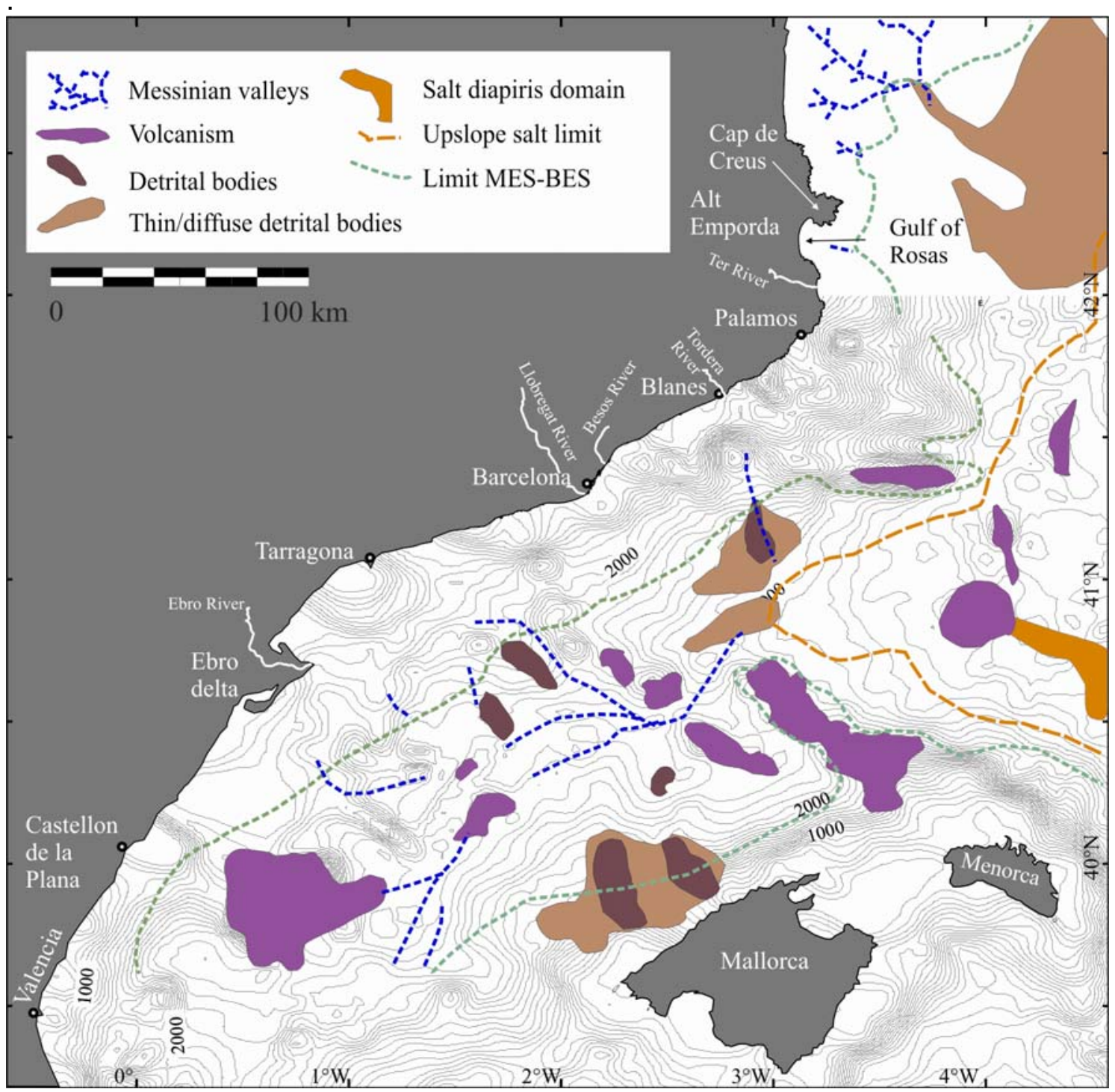


Figure 4. Methodology and dataset. a) Seismic profiles database analysed in this work, including information from the SIGEOF database (IGME) and data from research cruises. b) Examples of seismic profiles showing the criteria for the identification of the MES/TES.

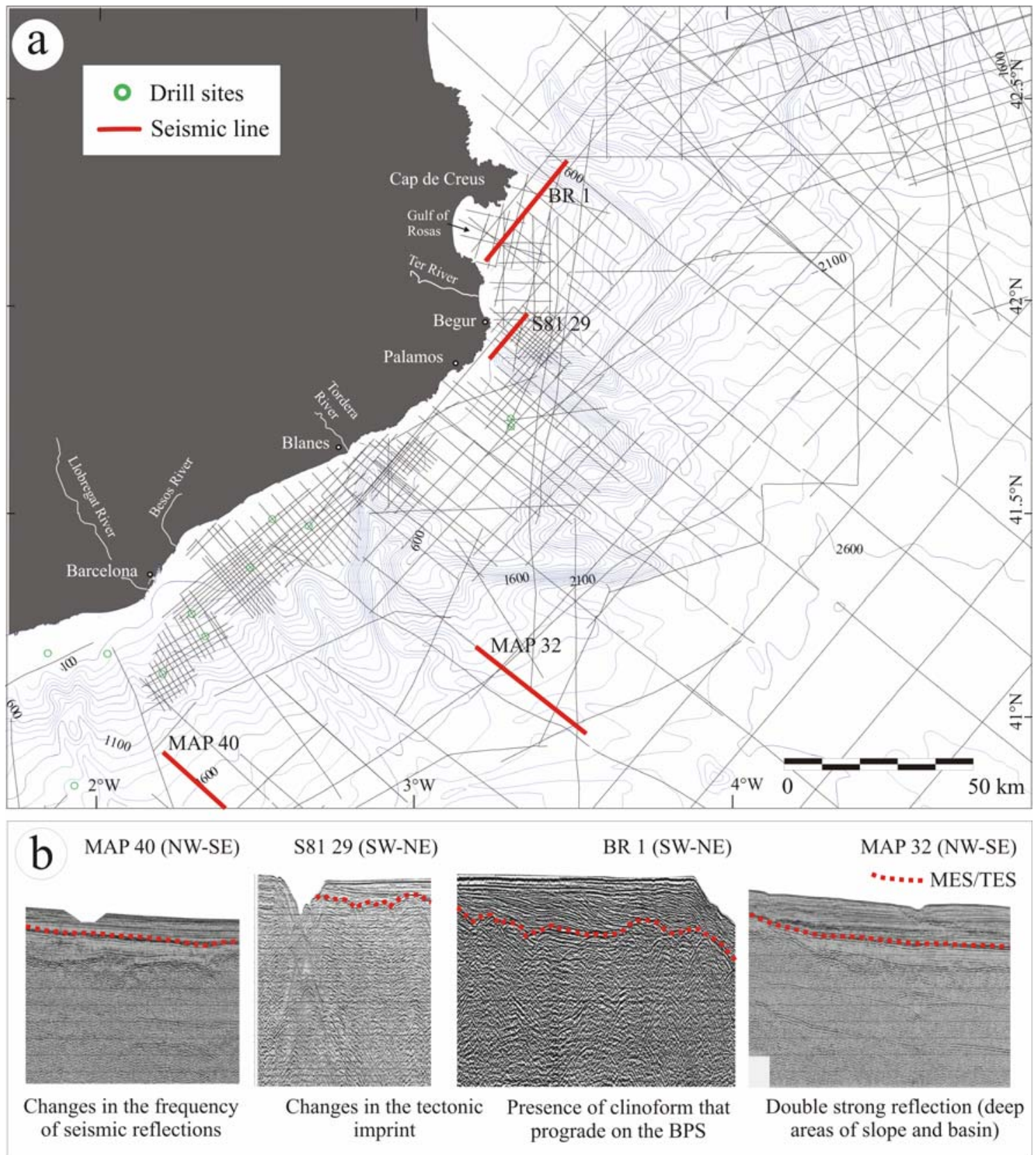


Figure 5. MES/TES isochrone (greyscale) and main morphological features identified on the Catalan margin. The area has been divided into the Creus, Girona and Barcelona domains (from north to south) based on the characteristics of the MES/TES. PDS: Paleo-drainage System.

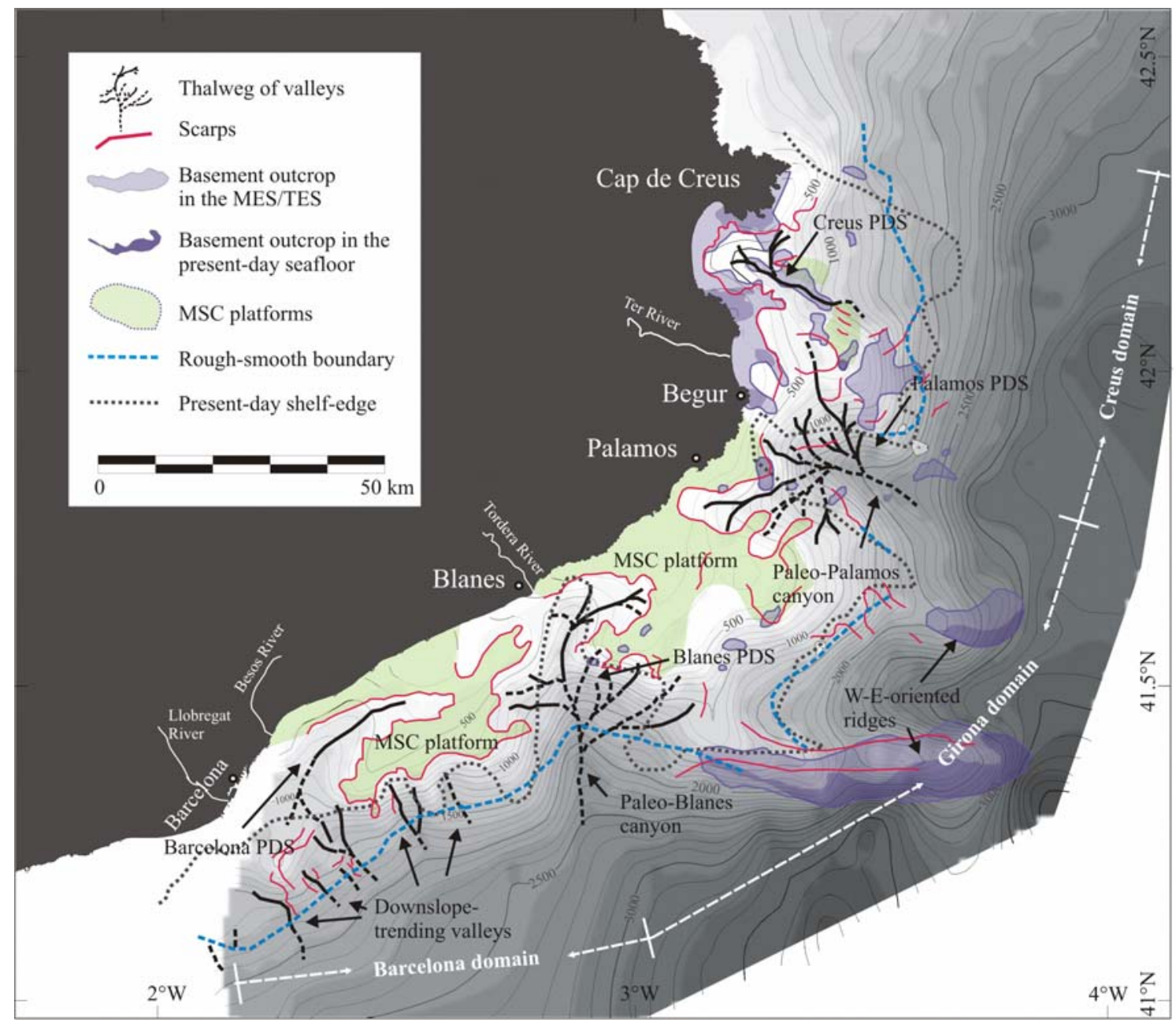


Figure 6. The Creus domain is the northernmost domain of the study area, limited to the south by the Palamós paleo-drainage system (PDS). a) Bathymetry of the MES/TES and location of the seismic profiles (see legend in Figure 5). b) to d) Seismic profiles showing the MES/TES, which coincides in many cases with the basement. White arrows mark the progradation of the Plio-Quaternary sediments on the MES/TES. Figure $6 \mathrm{~d}$ shows the mesa-like reliefs on the Creus PDS.

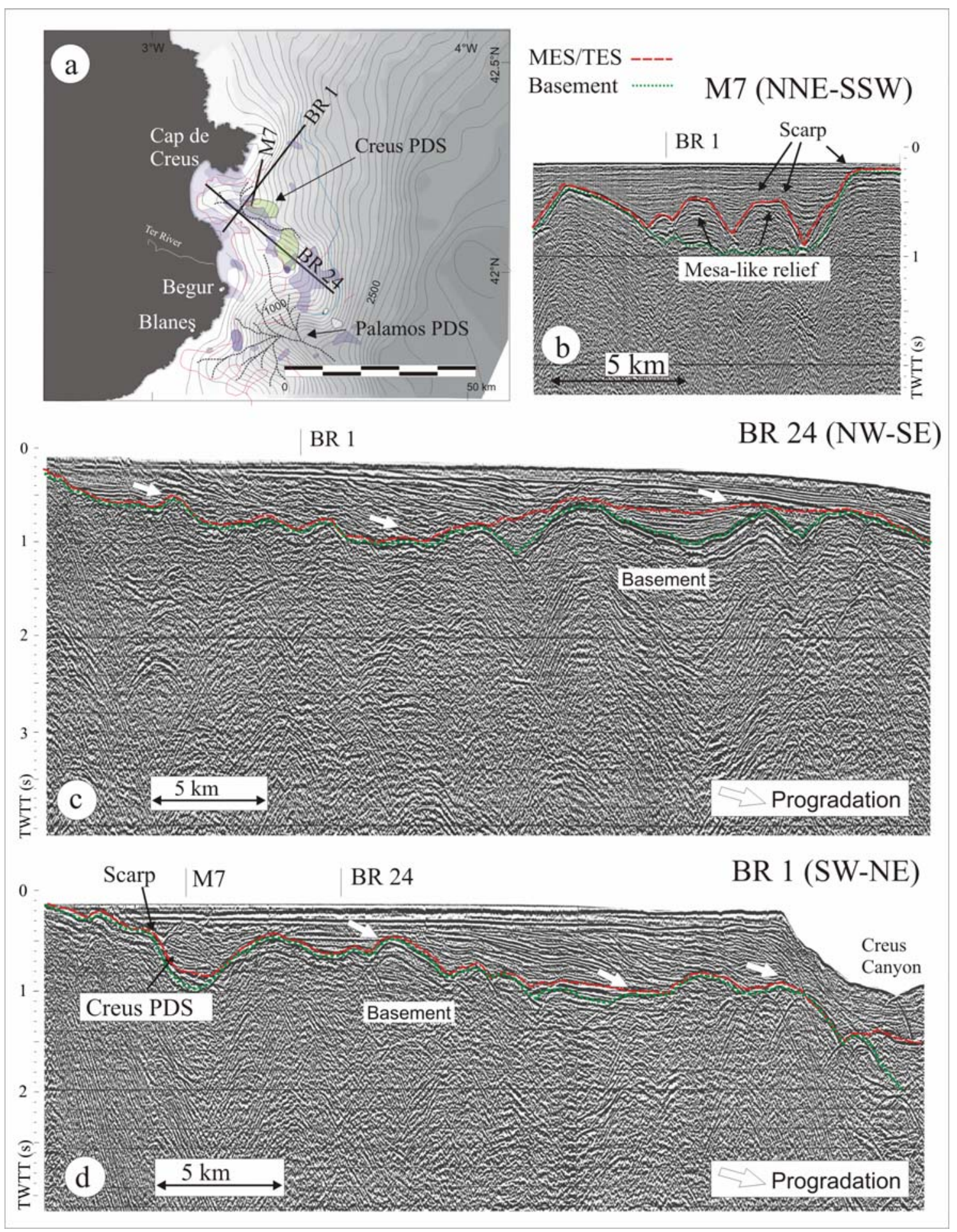


Figure 7. The Girona domain is limited by the Palamós PDS to the north and by the Blanes PDS to the south. a) Bathymetry of the MES/TES and location of the seismic profiles (see legend in Figure 5). b) and c) Seismic profiles showing the MES/TES and the basement. This domain is characterized by a wide and flat MCS platform.

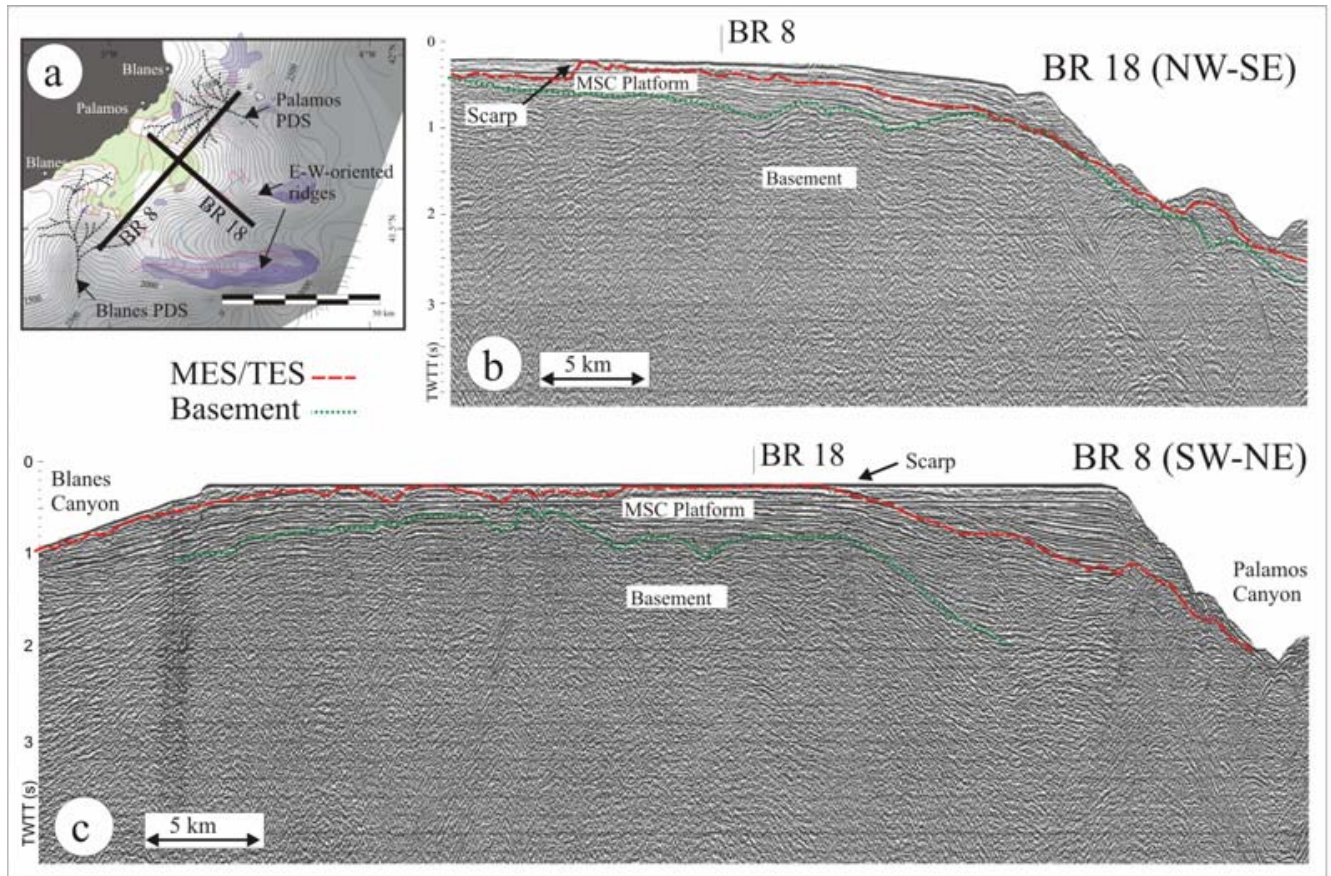


Figure 8. The Barcelona domain locates at the southern part of the study area, limited to the north by the Blanes PDS. a) Bathymetry of the MES/TES and location of seismic profiles (see legend in Figure 5). b), c) Seismic profiles showing the MES/TES and the basement. The MCS platform is cut by the Barcelona paleo-drainage system (Barcelona PDS).

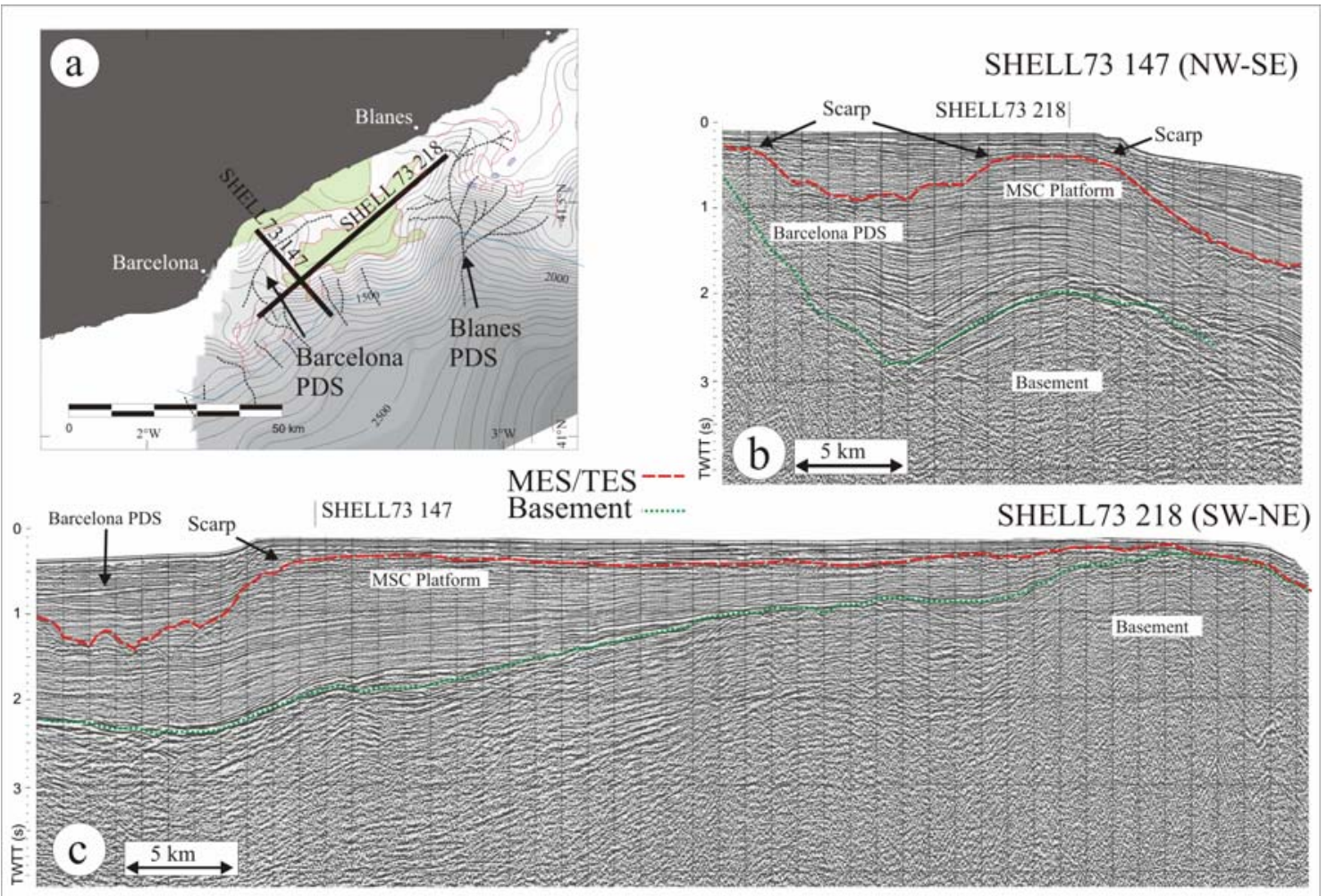


Figure 9. The Palamós present-day- and paleo-canyon. a) Bathymetry of the presentday (isobaths in $\mathrm{m}$ ) and paleo-canyon (isobaths in $\mathrm{ms}$ ). b) Seismic profiles showing the present-day and paleo-tranversal profile.
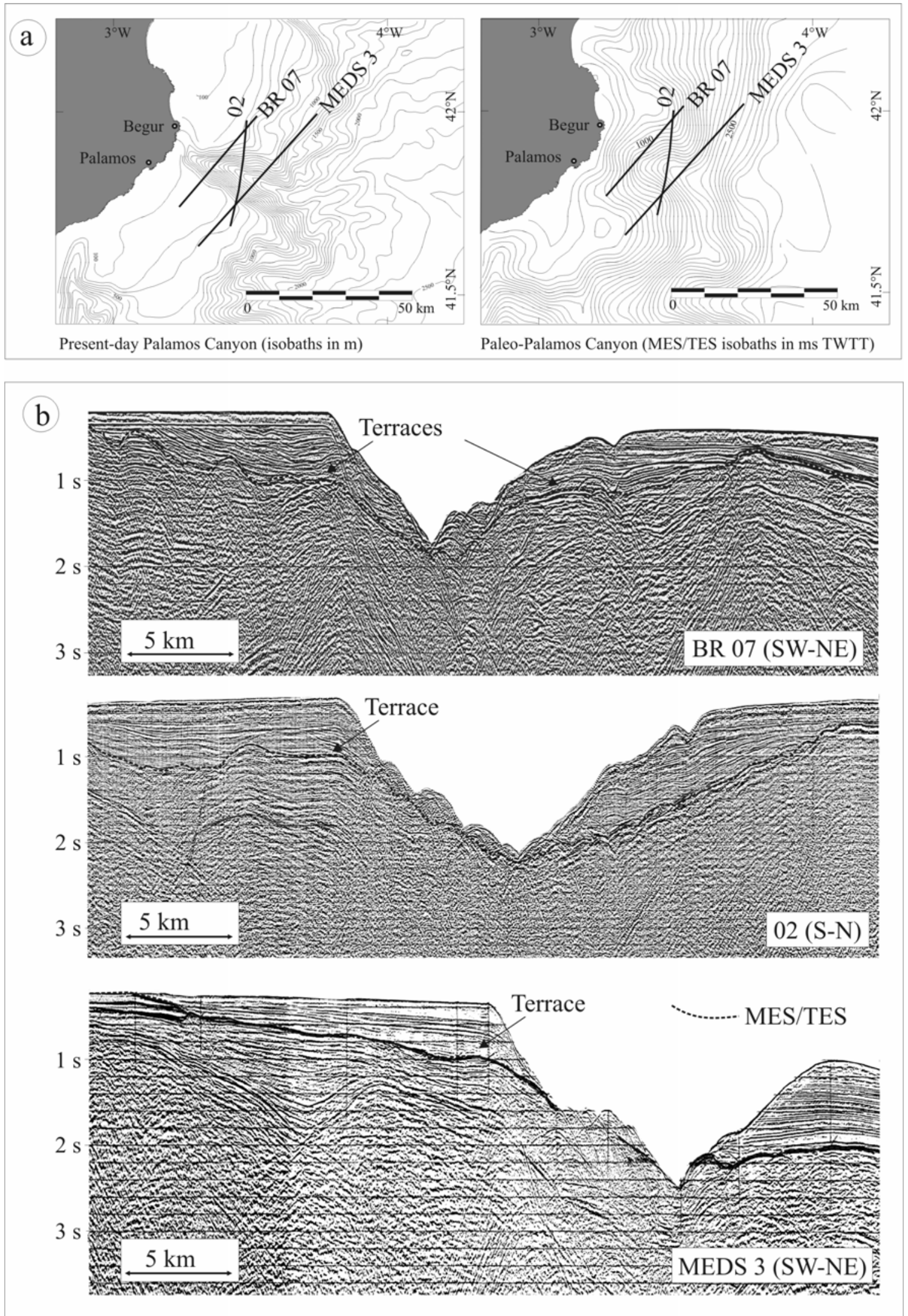
Figure 10. MSC erosional and depositional features. a) Map showing the rough-smooth boundary for the MES/TES, the upper limit of the detrital deposits and the distribution of the Upper and Mobile Units. b) Seismic profile showing the Messinian erosional surfaces (MES, TES, BES) and depositional units in the Valencia Basin.

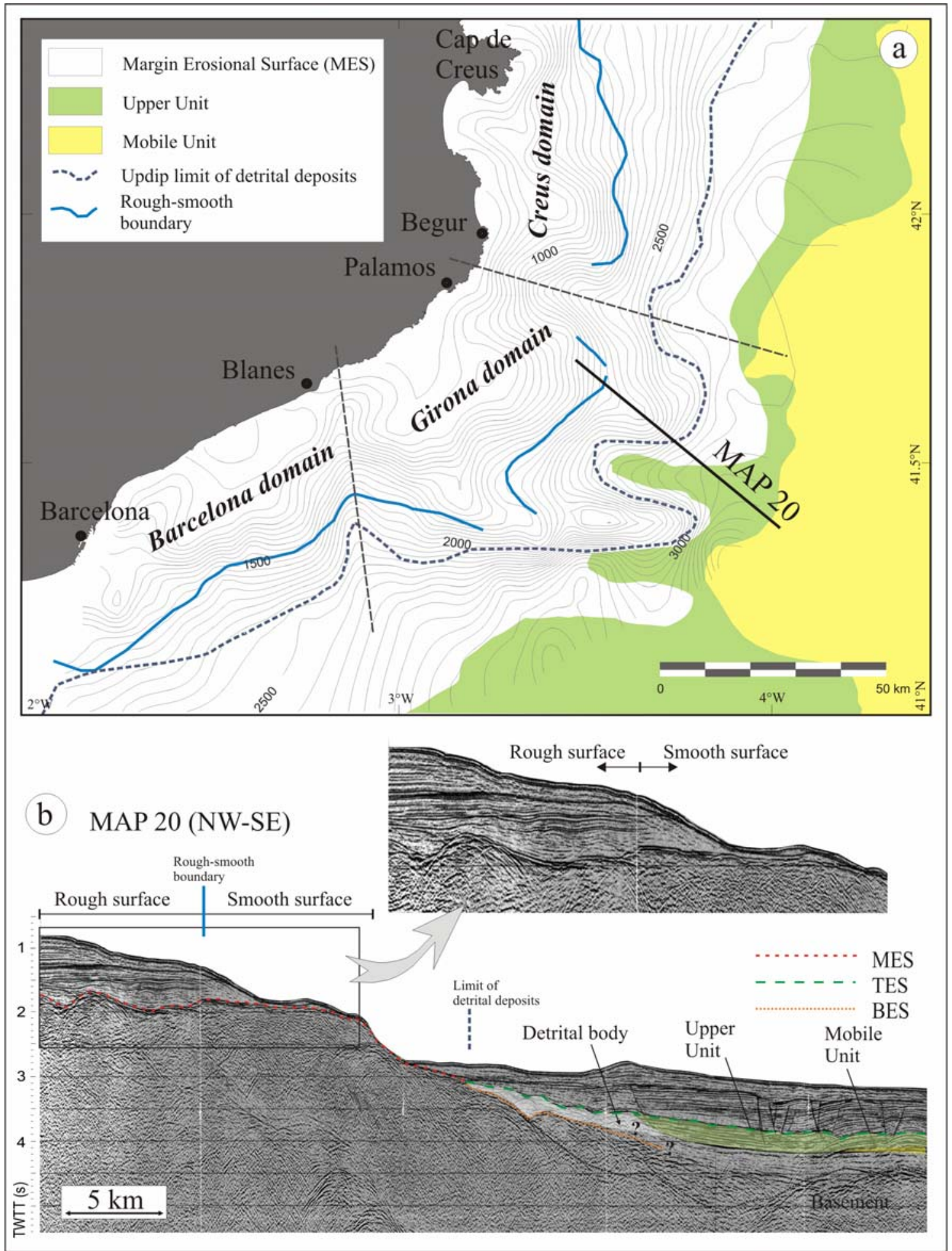


Figure 11. Isopachs of the Plio-Quaternary deposits (in ms TWTT) on the Catalan Margin, showing their uneven distribution. The present-day shelf-edge is marked for reference.

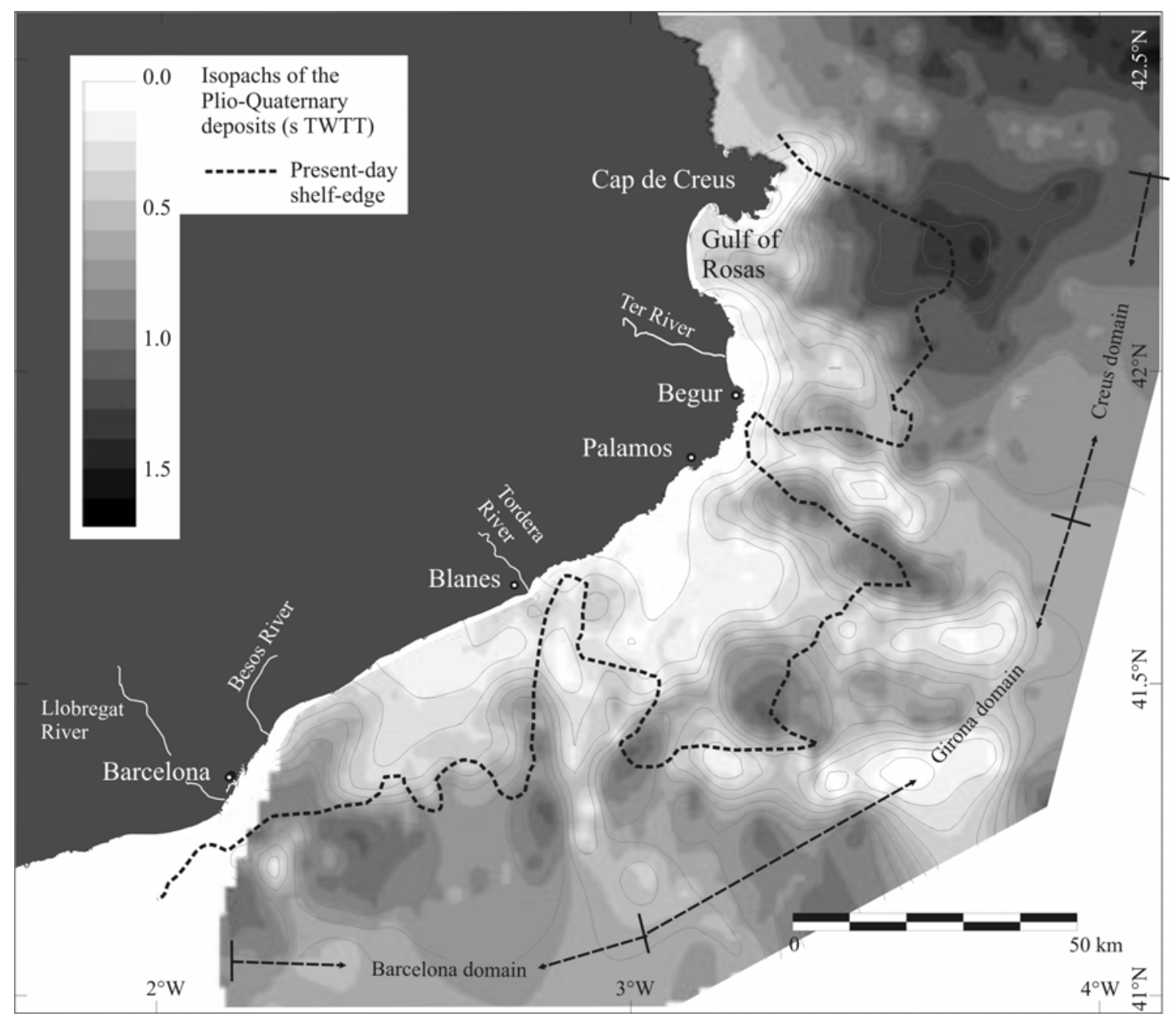


Figure 12. Schematic diagram of the sea level changes during the MSC and the resulting rough and smooth erosion surfaces and deposits on the continental shelf and slope.

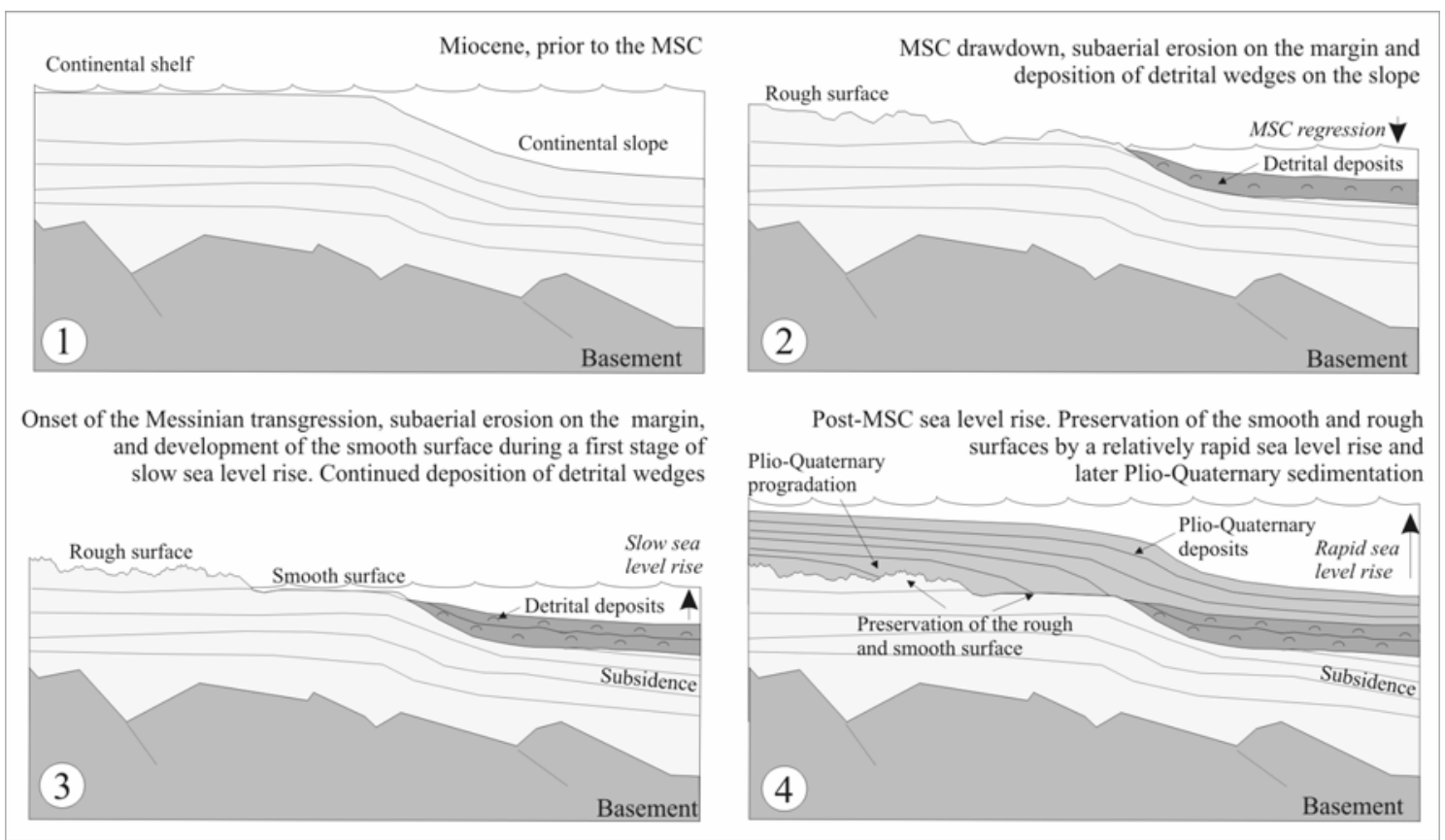

